\title{
Introducing Queer Theory to Turkey: Sel Publishing as an Agent in Turkish Culture Repertoire $^{1}$
}

\section{Kuir Kuramın Türkiye'ye Tanıtılması: Türk Kültür Repertuvarında Bir Aktör Olarak Sel Yayıncılık}

Research/Araştırma

\section{Büşra UL}

Res. Assist., Dokuz Eylül University, Faculty of Letters, Department of Translation and Interpreting, busra_ul@hotmail.com ORCID ID: 0000-0002-4738-2339

\begin{abstract}
Queer Studies is a relatively new field of study that brings queer identities into focus. Queer Studies became an independent research field during the 1970s and has gained momentum ever since. Despite its worldwide rising popularity, queer studies in Turkey are still at an early stage. Therefore, there is an enormous need for queer studies that focus on the Turkish context. As the Queer theory originated from the West, the first texts about the theory entered the Turkish nonliterary repertoire through translations. To that end, the translators as well as the publishing houses can be rendered as cultural agents that play an immense role in the introduction of queer notions and terms into the Turkish context. Taking this point of view as a starting point, this study aims at examining the position of Sel Publishing as a cultural agent concerning the introduction of queer non-fictional texts. The case study will be the two book series titled "LGBT Kitaplığı" and "Queer Düş'ün" and the total of fifteen books published under these series by Sel Publishing. These books will be evaluated within the concept of "culture repertoire" suggested by Even-Zohar (2002). In accordance with this framework, the reviews, interviews and critiques of these books as well as information about the translators will be analyzed. This analysis on
\end{abstract}

${ }^{1}$ This article is based on Büşra Ul's ongoing Ph.D. dissertation conducted at Dokuz Eylül University, Institute of Social Sciences, Translation Studies Ph.D. Programme. 
these two series as well as Sel Publishing will be discussed in a way to shed light on the agency of Sel Publishing within the Turkish culture repertoire on queer theory.

Key words: culture repertoire, Sel Publishing, cultural agent, queer studies

\section{ÖZET}

Kuir Çalışmaları, kuir kimlikleri odak noktasına alan nispeten yeni bir çalışma alanıdır. Kuir Çalışmaları 1970'lerde bağımsız bir araştırma alanı hâline gelmiş ve o zamandan bu yana bu alanda çalışmalar hız kazanmıştır. Her ne kadar bu alanın popülaritesi dünya çapında artmış olsa da, Türkiye'yi konu alan kuir çalışmaların hâlâ başlangıç aşamasında olduğunu söylemek yanlış olmaz. Bu nedenle, Türkiye bağlamını odak alan kuir çalışmalara ihtiyaç olduğu aşikârdır. Kuir Teori Batı'da ortaya çıkmış bir yaklaşım olduğundan, teori ile ilgili Türk kültür repertuvarına giren ilk metinler çeviri metinlerdir. Buna dayanarak, çevirmenler ve yayınevlerinin kuir kavram ve terimlerinin Türk repertuvarına tanıtılmasında çok önemli bir rol oynadığı yadsınamaz. Bu düşünceyi başlangıç noktası alarak, bu çalışma kuir metinlerin tanıtılması açısından kültürel bir aktör olarak Sel Yayıncılık'ın pozisyonunu incelemeyi amaçlamaktadır. Vaka çalışması olarak Sel Yayıncılık tarafından çıkarılan "LGBT Kitaplığı" ve "Queer Düş'ün" başıklı kitap serileri ve bu seriler kapsamında basılan on beş kitap seçilmiştir. Bu kitaplar Even-Zohar tarafından önerilmiş olan "kültür repertuvarı" (2002) kavramı çerçevesinde incelenmiştir. Bu çerçevede, bu kitaplar hakkında yazılmış olan eleştiri ve inceleme yazıları ile basılmış röportajlar incelenmiş; çevirmenler hakkında bulunan bilgiler de analize dâhil edilmiştir. Bu bağlamda, yayınevi ile bu seriler üzerine yapılan bu analiz kuir teori hakkında üretilmiş Türk kültür repertuvarı içerisinde Sel Yayıncılık'ın bir aktör olarak rolüne ışık tutması açısından değerlendirilmiştir.

Anahtar kelimeler: kültür repertuvarı, Sel Yayıncılık, kültür aktörü, kuir çalışmaları

\section{Introduction}

Queerness is not a brand new concept ${ }^{2}$ in Turkish culture repertoire considering the fact that the existence of queer individuals can be tracked in the historical texts that date back to the imperial period. Before the foundation of the Turkish Republic in 1923, the country was an empire, to be exact, Ottoman Empire. In the empire period, there was a concept of oğlancılık, "pederasty" in English, that captures our attention and indicates the existence of queer identities in Ottoman Empire. In the empire, this term was used for describing homosexual relationship between a man and a young boy and

\footnotetext{
${ }^{2}$ Herein, the concept of "queerness" refers to the queer identity of an individual. The concept of "queerness" and the term of "queer" are redefined after the proposal of the Queer Theory. Within the framework of Queer Theory, queerness refers to rejection of the heteronormativity which means the acceptance of heterosexuality as a primary norm of sexuality in a society and being queer means being against the notion of a fixed and stable sex or gender (Jagose, 1996, p. 3). That is to say, Queer Theory avoids of definitions and limitations in order to demonstrate that no gender or sexuality is 'natural' as it is perpetuated by the society.
} 
it was not seen as abnormality or worse, perversion; on the contrary, it was perceived as a part of everyday life (Bardakçı, 2006) ${ }^{3}$. The denunciation of queerness first started in Tanzimat Reform Era in 1840s and continued until the dissolution of the empire (Hür, 2013). After the dissolution and the establishment of the republic, a modern Turkey emerged and yet, disregarding public opinion towards queer identities and community persisted. And today, queerness is regarded as perversion and unnatural by the majority of the Turkish society ${ }^{4}$; accordingly, it is one of the taboo concepts in Turkish society in the same way as sexuality. Despite the marginal position of queer people, the queer themes and characters can still be tracked down in Turkish literary works and a great number of translations. Be that as it may, the introduction of queer theory and queer ideas within the context of gender studies is relatively new. The translations of academic writings, articles and essays on queer theory into Turkish have increased heavily in the 2010s with the publications such as Gey ve Lezbiyen Yazını (2011) by Hugh Stevens, Cinsellik ve Sosyalizm (2012) by Sherry Wolf, Queer Teori: Bir Giriş (2015) by Annamarie Jagose and Cinsiyet Belası (2016) by Judith Butler.

The aim of this study is to focus on the translated works and academic writings about queer theory in Turkey within a sociological perspective. In line with this aim, Sel Publishing is taken as a case study. Sel Publishing is one of the initiators that introduced the queer theory to Turkish nonliterary repertoire and sparked the debates on this subject as well as paved the way for new translations and indigenous texts about this subject. Sel Publishing created two series entitled "LGBT Kitaplığı" and "Queer Düş'ün" under which they published the translations of prominent works on queer theory and gender issues ${ }^{5}$ at first. Subsequently, they published three indigenous works under the "LGBT Kitaplığı" and another three under the "Queer Düş'ün”.

What ignited my interest on Sel Publishing is that it is the only publishing house that has not one but two book series devoted to the queer thought. Considering the fact that queer thought and queer community are still deemed as marginal in Turkish society, it is certainly intriguing for a publishing house to publish books under such series. This does not mean that there are no other publications on queer theory or thought; quite the contrary, there are plenty of literary works on this matter both fictional and non-fictional ${ }^{6}$. However, the systematic nature of these two series

\footnotetext{
${ }^{3}$ For further information, see Gelibolulu Mustafa Ali, 1978; Enderunlu Fazil, 2009.

${ }^{4}$ According to the Pew Global Attitudes Project: Spring 2007 Survey conducted by Pew Research Center, 57\% of the participants from Turkey is not open to accept homosexuality as a life style whereas $14 \%$ is positive about accepting homosexuality as a life style. See Pew Research Center (2007) and also www.kaosgl.com (2013).

${ }^{5}$ Sel Publishing has another series named "Kadın Kitaplığı" that focuses on gender issues; however, it is not included within the scope of this study.

${ }^{6}$ Non-fictional works such as Başkaldıran Bedenler: Türkiye'de Transgender, Aktivizm ve Altkültürel Pratikler (2013), Bela Bedenler (2014), Queer Teori: Bir Giriş (2015), Cinsiyet Belası (2016) and Toplumsal Cinsiyet
} 
indicates a deliberate action on the part of publishing house and thus, distinguishes them from the other nonliterary products of other publishing houses.

Within this mindset, Sel Publishing will be studied within the framework of culture repertoire and agents of translation. The two series and the discourse that surrounds them i.e. the reviews, interviews and critiques will be evaluated within the context of culture repertoire suggested by Even-Zohar (2002). This evaluation will help to reveal the position of Sel Publishing in Turkish nonliterary repertoire on queer thought. Subsequently, I will discuss and interconnect this position with the concept of 'agency' and at this point, the analysis on the abovementioned paratextual elements will be beneficial in determining the publishing house's position as an agent. In accordance with my purpose, this paper claims that Sel Publishing is a cultural agent that introduces queer theory to Turkish nonliterary repertoire.

\section{Culture Repertoire and Agents of Translation}

Even-Zohar defines the concept of "culture repertoire" as "the aggregate of options utilized by a group of people, and by the individual members of the group, for the organization of life" (2002, p. 166). In this definition, the concept of "options" is of paramount importance. The term "option" points out to the fact that there is an act of choice involved. It also allows us to reify the cultural products both substantial i.e. literary works and films and abstract i.e. notions and ideas. Moreover, he classifies the culture repertoire into two categories: "active" and "passive". Active repertoire is the active use of cultural goods by people in any situation whereas passive repertoire is the acquirement of the world as organized by an individual or a group. According to Even Zohar, there are two ways to create a culture repertoire and these are by "invention" and by "import". If an "import" is successfully integrated into the home repertoire, it will be deemed as a "transfer" (Tahir Gürçağlar, 2008, p. 40). However, this might not always be the case if an "import" encounters a "resistance" in home repertoire. This "resistance" might be a passive one which means the ignorance of the imported goods whereas an active resistance entails opposition and defiance. At this point, it should be emphasized that the concept of "options" which is a key concept for agent studies. Demircioğlu states, "it seems clear that 'option' points to agents who are involved in active decision-making" (2009, p. 134). To put differently, it is the agents that decide the "options" that may or may not turn into "imports" and later "transfers". This fact certainly vests great power in agents, to be specific, cultural agents. But who are these agents? To provide a reply to this question, Milton and Bandia defines an agent as an entity e.g. a translator, an institution or a magazine that ignites cultural change $(2009$, p. 1). Certain agents might make a difference within the

Tartışmaları (2016). Fictional works such as Her Gece Bodrum (1977), Hergele Aşıklar (2003), Sevişen Çocuklar Matinesi (2007), Ali ile Ramazan (2010), Queer (2014) and so forth. 
context of translation and lay the foundations of new trends in translations. On the other hand, certain agents may entail much more force that may create a cultural and political influence.

The studies on agents of translation gained momentum with the rise of sociological approaches in Translation Studies and the difference of these studies from the previous ones is that they have a broader perspective that covers both social and cultural surroundings as well as professional backgrounds. Buzelin names two types of agent studies: the ones that focus on translation history and the others that benefit from the methods in anthropology or qualitative sociology and these studies usually focus on the contemporary cases $(2011$, p. 8). Agent studies about translation history usually examine important historical figures of political, literary or cultural history ${ }^{7}$. On the other hand, the studies within the sociological and ethnographic perspective pertain contemporary field of interests ${ }^{8}$. These studies contain surveys about translators and the translations, interviews with translators or institutions, ethnographies of settings in which the act of translation occurs.

This study falls under the second category of agent studies. Sel Publishing started the first series "LGBT Kitaplığı" in 2011 and the last publication that comes out under the series is Ah Bu Sevda! - Türk Edebiyatında "Öteki" Cinsellik Öyküleri 18721928 which was published in June 2020. To that end, I carried out detailed research about the reception of the books through reviews, interviews and critiques. This research will play a significant part for determining the role of Sel Publishing within the context of queer theory texts in Turkish nonliterary repertoire. Finally, my research will attempt to find an answer for the question of whether we can regard Sel Publishing as a cultural agent or not.

\section{Queer Studies and Queer Translation}

Queer studies started as a branch of gender studies and later it became an independent research field under the name of "Lesbian and Gay Studies" in the 1970s. The emphasis of these studies was mainly "uncovering the suppressed history of gay and lesbian life" (Branch, 1986, p. 21). When the studies on lesbian and gay identities gained popularity, the name of the field also raised questions and concerns about its inclusivity. Other members of lesbian and gay community such as transgenders, bisexuals, and intersex people felt left out and that created a need for an allencompassing term to include every different member of this community. Therefore, the term 'queer' which used to be an insult for the individuals of lesbian, gay, bisexual, transsexual/transgender and intersexual (LGBTI) community was recontextualized and appropriated by the same community as an umbrella term so that it offers an all-

\footnotetext{
7 See Tahir-Gürçağlar, 2009; Demircioğlu, 2009; Bastin, 2009.

${ }^{8}$ See Koskinen, 2008; Sela-Sheffy \& Shlesinger, 2008.
} 
encompassing concept that includes all these identities under its roof. Accordingly, this particular research field which was referred to Lesbian and Gay Studies were renamed as "Queer Studies" in order to include other gender types. Following the rising interest in studies about queer identities, queer theory was conceived and introduced in the 1990s (Jagose, 1996, p. 2). Queer theory suggests that the sexual identities are socially constructed and the boundaries that surround gender norms are not as strict as it was perpetuated in the society. After the inception of queer theory, numerous brilliant works that focus on this theory were carried out by academics ${ }^{9}$.

Despite the abundance of studies on queer theory in different academic fields such as literature, film studies, politics and cultural studies, the field of Translation Studies has yet to integrate with queer studies. Thus, it can be suggested that queer translation is a relatively new subfield of study within Translation Studies. The studies on queer translation started with Keith Harvey. He can be recognized as a forerunner in this line of study as his studies are remarkable contributions to queer translation studies that paved the way for further research on the field. His best-known study is "Translating Camp Talk: Gay Identities and Cultural Transfer" (1998) in which he examines the difference that occur in the translation of camp talk between English French language pair is considered one of the groundbreaking studies on this subject. He published a great number of other studies on queer translation ${ }^{10}$ and his main research interest is the camp talk which is a sociolect that is talked by homosexuals. In relation to camp talk, he also explored the question of gay identity in his studies.

Christopher Larkosh is another key figure in queer translation studies. Similar to Harvey, Larkosh's main field of interest is queer identities and he focuses on certain cases in Argentine culture. Re-engendering Translation: Transcultural Practice, Gender/Sexuality and the Politics of Alterity (2011) can be regarded as his most notable work which he co-edited and to which he contributed with a chapter. Additionally, he has a number of published articles that tackles the issue of queerness within the context of translation studies ${ }^{11}$.In similar vein, Brian James Baer and Luise von Flotow are other noteworthy academicians that made contributions to this field ${ }^{12}$. Together with Klaus Kaindl, Baer (2018) contributed to one the most significant books of the field entitled Queering Translation, Translating the Queer: Theory, Practice, Activism. The book is a compilation of studies that were presented in the conference of same title, held in Vienna, Austria in 2015. Baer (2020) also recently wrote a book entitled Queer Theory and Translation Studies: Language, Politics, Desire on this field. Furthermore, Queer in Translation edited by B. J. Epstein and Robert Gillett (2017) is another important book in the field of queer translation studies as this book includes

\footnotetext{
${ }^{9}$ See Jagose, 1996; Butler,1990; Halberstam, 2005; Fryer, 2010.

${ }^{10}$ See Harvey, 1997, 2000a, 2000b, 2000c, 2003a, 2003b.

${ }^{11}$ See Larkosh, 2006, 2007a, 2007b.

${ }^{12}$ See Baer, 2011, 2014; Flotow, 1999, 2012.
} 
significant studies on various factors and elements influencing the translation process of queer texts.

Queer studies in Turkey are relatively new compared to the studies around the world. Even though queer themes are adopted in literature and films since the 1960s, introduction of queer theory is delayed until the 2010s. Therefore, the texts about queer theory really boom in Turkish culture repertoire after 2010s. That being the case, queer themes and characters in Turkish cinema starts with the movie Ver Elini Istanbul in 1962. In this movie, a scene in which two women kiss takes place (Öztek, 2007, p. 2). Following this film, iki Gemi Yanyana that came out in 1963 includes another lesbian kiss scene whereas Haremde Dört Kadın in 1965 depicts the lesbian relationships among women in a harem. Between the years of 1974 and 1979, lesbian relationships took place as a way of exploitation and for the sake of commercial purposes in sexual comedies in Turkish cinema (p. 6). The first depiction of gay relationship in Turkish film repertoire appears in Beddua (1980). After these films, many contemporary Turkish films deal with queer issues, contain queer characters and depict queer relationships. To name a few, istanbul Kanatlarımın Altında (1996), Hamam (1997), Ağır Roman (1997), Iki Genç Kız (2005) and Güneşi Gördüm (2009).

Queer themes in Turkish literary repertoire can be found in earlier texts such as Hûbân-nâme (Güzel Oğlanlar Kitabı) by Enderûnlu Fazıl who is a $18^{\text {th }}$ century poet as well as Dellâkname-i Dilküşâ (Gönüller Açan Tellâklar Kitabı) written in $17^{\text {th }}$ century by Hamamcılar Kethüdası Derviş İsmail (Altunpolat, 2013). Furthermore, in 1910, Baha Tevfik's stories Ah Bu Sevdâ and Aşk Hodbini; along with Mehmet Rauf's Bir Zambak Hikâyesi include queer characters (Soydan, 2020, p. 133). At the beginning of the newly founded Republic of Turkey, it seems that there is dry period for queer themes in Turkish novels, considering the fact that no such traces can be found in the novels of that period. In the modern Turkey after the foundation Republic, the first novel that centers around a gay character is Her Gece Bodrum written by Selim Ileri in 1977 (Şevki, 2009, p. 259). The queer themes continue with Atilla ilhan's Fena Halde Leman (1980). In addition to this novel, IIhan wrote two more novels entitled Dersaadette Sabah Ezanları (1981) and Haco Hanım Vay (1984) that revolve around the same theme. It is worth noting that Illhan is one of the most prominent authors and poets in modern Turkish literature and thus, the fact that he tackles the subject of queerness might have drawn the attention of the public to this concept. Other notable works that involve queer themes are Son Istanbul (1985) by Murathan Mungan, Kılavuz (1990) by Bilge Karasu, Leyla ile Şirin (1992) by Hülya Serap Doğaner, Bella (2002) by Stella Aciman, Travesti Pinokyo (2002) by Sibel Torunoğlu, Üçüncü Tekil Şahıs (2003) by Mehmet Bilal, Kurtlu Elma Şekeri (2003) by Pınar Orhan Küzeci, Deniz Kızı (2003) by Zeynep Aksoy, Paramparça (2004) by Duygu Asena, Volkan'ın Romanı (2006) by Ahmet Tulgar, Aşkın L Hali (2009) by Kaos GL Kadın Grubu, Gizli Anların Yolcusu (2011) and Bora'nın Kitabı (2012) by Ayşe Kulin, iki Genç Kızın Romanı (2002) and Ali ile Ramazan (2010) by Perihan Mağden, Ben Senin Bildiğin Erkeklerden Değilim (2012) by Murat 
Renay, Sevişen Çocuklar Matinesi (2007) and Fişini Sen Mi Çektin Rüyalarımın (2011) by Çağlar Yerlikaya, Yine Doğdu Tanyıldızı (2014) by Gürsel Korat, Kardeşimin Hikayesi (2016) by Zülfü Livaneli and Deccal'in Hatırı (2014a), Kısas (2014b) and Son Şûrâ (2021) by Sezgin Kaymaz.

The publications of nonfiction texts on queer theory in Turkish repertoire start with translations such as Cinsel Çeşitlilik: Yönelimler, Politikalar, Haklar ve Ihlaller (2004) by Vanessa Baird, Cinsiyet Belası: Feminizm ve Kimliğin Altüst Edilmesi (2008) by Judith Butler and Toplumsal Cinsiyet Yanılsaması (2011) by Cordelia Fine. It seems worth noting that Toplumsal Cinsiyet Yanılsaması, which is the translation of Delusions of Gender: How Our Minds, Society, and Neurosexism Create Difference (2010), is translated by Kıvanç Tanrıyar and published under the series of "LGBT Kitaplığı" of Sel Publishing. Despite of the fact that this book is not about queer theory, per se, it tackles the issue of gender construct and the myths about the hardwired differences between the brains of men and women. Therefore, this could be the reason why this book is published under the series of "LGBT Kitaplığı" by Sel Publishing ${ }^{13}$. The agency of Sel Publishing on the introduction of queer theory into Turkish culture repertoire will be further discussed in detail. Similarly, Metis Publishing has a key role in the publications on queer theory. In addition to Cinsel Çeşitlilik: Yönelimler, Politikalar, Haklar ve ihlaller and Cinsiyet Belası: Feminizm ve Kimliğin Altüst Edilmesi, Metis published other works on this topic such as Cinsellik Muamması: Türkiye'de Queer ve Muhalefet (2012) edited by Cüneyt Çakırlar and Serkan Delice and Başkaldıran Bedenler: Türkiye'de Transgender, Aktivizm ve Altkültürel Pratikler (2013) edited by Berfu Şeker. At this point, it should be emphasized that there are two books named Eşcinsel Erkekler: Yirmi Beş Tanıklık and Eşcinsel Kadınlar: Yirmi Dört Tanıklık which were published by Metis respectively in 2002 and 2003. These books describe the different experiences of twenty-five gay and twenty-four lesbian individuals in Turkey. Even though the books are not academic studies on queer theory, they are important in revealing the experiences of the members of the queer community and certainly significant contributions to the queer studies in Turkey. Another notable publication is the journal of Kaos GL Dergi which has been published since 1994. The journal has been handling queer issues with an academic and socio-political perspective and publishing numerous literary and academic translations (KAOS GL Derneği, 2020, para. 1). Moreover, this journal is a very significant part of queer movement in Turkey. In 2000, the organization, which was yet to be official, opened a center named "KAOS Cultural Center" (para. 4). In 2005, the publishers of Kaos GL Dergi gained an official status as an activist organization named KAOS $\mathrm{GL}^{14}$ which is short for Kaos Gay and Lesbian Cultural Research and Solidarity Association. Furthermore, together with

\footnotetext{
${ }^{13}$ For further information, visit https://www.selyayincilik.com/kitap/toplumsal-cinsiyet-yanilsamasi-707

${ }^{14} \mathrm{KAOS}$ GL is a civil-rights organization which started its journey as an Ankara-based journal in 1994 and became an activist association in 2005. Both the journal and the association are still active and continue to fight with prejudices, homophobia and transphobia.
} 
NotaBene Publishing, KAOS GL translated and published Queer Teori: Bir Giriş (2015). It is the translation of Annamarie Jagose's groundbreaking study Queer Theory: An Introduction which is one the most important reference books in the field of queer studies. In 2014, the organization started to annually publish a refereed journal titled KaosQueer+ (para. 12).

Academic studies that focus on queer studies within the context of Turkey increased at the beginning of 2010. There is a number of MA theses and unpublished Ph.D. dissertations that focus on queer theory and queer identities in Turkey. These studies are carried out by Özbay, 2005; Özer, 2005; Albayrak, 2009; Ertetik, 2010; Mutlu, 2012; Keniş, 2012; Hazar, 2012; Çetin, 2013; Bolat, 2013; Kunt, 2013; İ̧, 2013; Çalışkan, 2014; Levent, 2015; Karalı, 2015; Balkan, 2016; Doğan, 2016; Cabadağ, 2016; Candemir, 2016; Tiftik, 2017; Demiral, 2017; Kılıç, 2018; İmançer, 2018; Büyüközer, 2018; Güney, 2018; Yılmaz, 2019; Yüce, 2019; Akgün, 2019; Demirel, 2019; Alsamua, 2019; Şimşek Aksin, 2019; Tanır, 2019; Küçükvatan, 2019; Topal, 2019; Aktaş, 2019; Tunçsan, 2019; Altay, 2019; Hamamcıoğlu, 2020; Erdoğan, 2020; Duman, 2020; Gülhaş, 2020; Çetin, 2021.

At this point, a parallelism can be drawn between the academic studies and the publications on queer theory which have increased in number during the 2000 s as stated above. Thus, it can be suggested that academic studies and the translations go hand in hand in Turkish cultural repertoire. On the other hand, the studies on the concept of queer translation within context of Turkish culture repertoire are really scarce. A couple of academic studies on queer translation in Turkish context were conducted by Savcı, 2011, 2021; UI, 2016; Solmaz, 2018; Susel, 2019; Sancaktaroğlu Bozkurt, 2019.

\section{Sel Publishing as a cultural agent}

Sel Publishing was established in the year of 1990 and published political texts and research about the political and cultural turmoil in Turkey as well as the translations and copyright works of journalists at the beginning (Sel Yayıncılık, 2016, para. 1). In the midst of 90s, Sel Publishing managed to diversify its publications with both fiction and non-fiction literary works and continues to become one of the respected publishing houses in Turkey. Sel Publishing retains a wide range of fields of interests from women's studies and sexual studies to translation studies and history.

One aspect of Sel Publishing that sets it apart from its peers is the two book series dedicated to queer studies. "LGBT Kitaplığı" and "Queer Düş'ün" comprise a total of fifteen books and all of these books focus on either queer theory or queer identities. Nine of these books are translations, three of them are indigenous texts and the other three are compilations which are composed of both translations and indigenous texts. The translations are mainly from English or French into Turkish. The 
books in two series are given in the two following tables. The first table covers the books of "LGBT Kitaplığı".

Table 1

The list of books under the series "LGBT Kitaplığı"

\begin{tabular}{|c|c|c|c|c|c|}
\hline & Title of the Book & Title of Original & Writer & Translator & $\begin{array}{c}\text { Publication } \\
\text { Date }\end{array}$ \\
\hline 1. & $\begin{array}{c}\text { Ah Bu Sevda! - } \\
\text { Türk } \\
\text { Edebiyatında } \\
\text { "Öteki" Cinsellik } \\
\text { Öyküleri 1872- } \\
1928\end{array}$ & $\begin{array}{l}\text { Indigenous } \\
\text { Turkish Text }\end{array}$ & $\begin{array}{l}\text { Serdar } \\
\text { Soydan }\end{array}$ & - & June 2020 \\
\hline 2. & $\begin{array}{l}\text { Homofobi } \\
\text { Sözlüğü }\end{array}$ & $\begin{array}{l}\text { Dictionnaire de } \\
\text { L'Homophobie }\end{array}$ & $\begin{array}{l}\text { Louis- } \\
\text { Georges } \\
\text { Tin }\end{array}$ & $\begin{array}{l}\text { Melis Tezkan, } \\
\text { Okan Urun }\end{array}$ & June 2018 \\
\hline 3. & Göğe Kuşak Lazım & $\begin{array}{l}\text { Indigenous } \\
\text { Turkish Text }\end{array}$ & $\begin{array}{l}\text { Ahmet } \\
\text { Güneş }\end{array}$ & - & March 2016 \\
\hline 4. & Öteki Erkekler & $\begin{array}{l}\text { Indigenous } \\
\text { Turkish Text }\end{array}$ & $\begin{array}{c}\text { Aras } \\
\text { Güngör }\end{array}$ & - & July 2013 \\
\hline 5. & $\begin{array}{l}\text { Cinsellik ve } \\
\text { Sosyalizm }\end{array}$ & $\begin{array}{l}\text { Sexuality and } \\
\text { Socialism }\end{array}$ & $\begin{array}{c}\text { Sherry } \\
\text { Wolf }\end{array}$ & $\begin{array}{c}\text { Kıvanç } \\
\text { Tanrıyar }\end{array}$ & April 2012 \\
\hline 6. & $\begin{array}{c}\text { Gey ve Lezbiyen } \\
\text { Yazını }\end{array}$ & $\begin{array}{c}\text { The Cambridge } \\
\text { Companion to } \\
\text { Gay and Lesbian } \\
\text { Writing }\end{array}$ & $\begin{array}{l}\text { Hugh } \\
\text { Stevens } \\
\text { (Ed.) }\end{array}$ & $\begin{array}{l}\text { Kıvanç } \\
\text { Tanrıyar }\end{array}$ & October 2011 \\
\hline 7. & $\begin{array}{l}\text { Toplumsal } \\
\text { Cinsiyet } \\
\text { Yanılsaması }\end{array}$ & $\begin{array}{l}\text { Delusions of } \\
\text { Gender: How } \\
\text { Our Minds, } \\
\text { Society, and } \\
\text { Neurosexism } \\
\text { create } \\
\text { Difference }\end{array}$ & $\begin{array}{l}\text { Cordelia } \\
\text { Fine }\end{array}$ & $\begin{array}{l}\text { Kıvanç } \\
\text { Tanrıyar }\end{array}$ & March 2011 \\
\hline
\end{tabular}

The following second table indicates the books published under the series of “Queer Düş'ün”15.

${ }^{15}$ As of 2019, Berfu Şeker, Gülkan 'Noir', Leman Sevda Darıcıoğlu and Pınar Büyüktaş who are the translators and the editors of "Queer Düş'ün" series made a statement that they parted ways with Sel Publishing and 
Introducing Queer Theory To Turkey: Sel Publishing As An Agent In Turkish Culture Repertoire

Table 2

The list of books under the series "Queer Düş'ün”

\begin{tabular}{|c|c|c|c|c|c|}
\hline & Title of the Book & Title of Original & Writer & Translator & $\begin{array}{c}\text { Publication } \\
\text { Date }\end{array}$ \\
\hline 1 & King Kong Teori & $\begin{array}{l}\text { King Kong } \\
\text { Théorie }\end{array}$ & $\begin{array}{c}\text { Virginie } \\
\text { Despentes }\end{array}$ & $\begin{array}{l}\text { Leman Sevda } \\
\text { Darıcıoğlu- } \\
\text { Pınar Büyüktaş }\end{array}$ & $\begin{array}{l}\text { December } \\
2016\end{array}$ \\
\hline 2 & Mutluluk Vaadi & $\begin{array}{c}\text { The Promise of } \\
\text { Happiness }\end{array}$ & Sara Ahmed & $\begin{array}{c}\text { Deniz } \\
\text { Mayadağ }\end{array}$ & June 2016 \\
\hline 3 & Queer Temaşa & $\begin{array}{l}\text { Indigenous } \\
\text { Turkish Text }\end{array}$ & Collective & $\begin{array}{c}\text { Leman S. } \\
\text { Darıcıoğlu } \\
\text { (Editor) }\end{array}$ & $\begin{array}{c}\text { February } \\
2016\end{array}$ \\
\hline 4 & $\begin{array}{c}\text { Duyguların Kültürel } \\
\text { Politikası }\end{array}$ & $\begin{array}{c}\text { The Cultural } \\
\text { Politics of } \\
\text { Emotion }\end{array}$ & Sara Ahmed & Sultan Komut & April 2015 \\
\hline 5 & Fetiş ikâme & $\begin{array}{l}\text { Indigenous } \\
\text { Turkish Text }\end{array}$ & Collective & $\begin{array}{c}\text { Tuna Erdem - } \\
\text { Seda Ergül } \\
\text { (Editors) }\end{array}$ & $\begin{array}{c}\text { December } \\
2014\end{array}$ \\
\hline 6 & $\begin{array}{l}\text { Çuvallamanın } \\
\text { Queer Sanatı }\end{array}$ & $\begin{array}{c}\text { The Queer Art } \\
\text { of Failure }\end{array}$ & $\begin{array}{c}\text { Judith } \\
\text { Halberstam }\end{array}$ & İpek Tabur & October 2013 \\
\hline 7 & Straight Düşünce & $\begin{array}{l}\text { La Pensée } \\
\text { Straight }\end{array}$ & $\begin{array}{l}\text { Monique } \\
\text { Wittig }\end{array}$ & $\begin{array}{l}\text { Leman Sevda } \\
\text { Darıcıoğlu- } \\
\text { Pınar Büyüktaş }\end{array}$ & May 2013 \\
\hline 8 & Queer Tahayyül & $\begin{array}{l}\text { Indigenous } \\
\text { Turkish Text }\end{array}$ & Collective & $\begin{array}{l}\text { Sibel Yardımcı, } \\
\text { Özlem Güçlü } \\
\text { (Editors) }\end{array}$ & $\begin{array}{c}\text { February } \\
2013\end{array}$ \\
\hline
\end{tabular}

In an interview with Sel Publishing conducted by Alpar (2019), they indicate that Sel Publishing tries to listen to social movements, academy discussions and the voices on the street in both Turkey and the world since it was founded in 1990 (para. 6). In line with their purpose of focusing on different matters, they started the series with the names of "Kadın Kitaplığı" and "LGBT Kitaplığı" which were born from the need to contribute to the literature (para. 7). After these two series, they realized that queer thought and queer issues need to be handled under a different title, independent from the "Kadın Kitaplığı" and "LGBT Kitaplığı". That is when the series of "Queer Düş'ün" was conceived. This decision taken by Sel Publishing can be rendered as what Sela-Sheffy deemed as "receptive attitude". Sela-Sheffy defines this concept as "at a certain point, extraneous repertoire becomes valuable for a certain social group,

explained that there were ongoing communication problems between the two parties (Kaos GL, 2019, para. 6). Accordingly, there are no further publications from “Queer Düş'ün” since 2016. 
which 'thinks of itself' as 'lacking', or rather, 'in need' of it" (Sela-Sheffy, 2003, p. 5). It is also noteworthy to mention that Sel Publishing is the first and only publishing house that publishes non-fiction queer texts in a systematic way as two book series as online data research revealed. Accordingly, it is safe to say that the systematic nature of these series and the deliberateness of Sel's actions can be taken as indicators of the Sel Publishing's agency.

In another interview with the publishing house, the owner Irfan Sancı accepted that Sel Publishing made contributions to the increasing interest towards queer theory (Uzunoğlu, 2015, p. 9). He added that he is happy with these contributions. He also expressed that there were challenging points in both translations and indigenous texts within these series and they would be more careful and attentive about the forthcoming translations (p. 9). Finally, he pointed out that Sel Publishing is persistent in publishing new books under the series such as "Queer Düş'ün”, "Kadın Kitaplığı" and "LGBT Kitaplığı". The fact that Sel Publishing recognized their contributions to the literature strengthens the claim of Sel Publishing's agency. Moreover, the confirmation of the translations, compilations and also, indigenous texts published under the series is important for the scope of this study. At this point, it should be indicated that the analysis will start with translations and compilations and then, discuss the indigenous texts in order to see the improvement of the queer nonfiction texts within the framework of the concepts of "import", "transfer" and "invention".

\subsection{Analysis of the books}

Chesterman (2007) states that sociological research in translation studies involves topics such as the market of translation, the role of the agents within the publishing industry and the roles played by the translators and the profession of the translators which can be also named as agents (p. 173). He further explains that the focus on sociological studies is people and the observable actions of people (p. 174). Taking this notion into account, a sociological research on the "observable actions" of the publishing house and the translators will be carried in order to determine their roles within the conception the new culture repertoire of nonliterary queer literature. Furthermore, the analysis on the reviews, interviews and critiques will explicate how these "imports" are received in the target culture and whether they were evolved into "transfers" and later, "inventions".

The first published book, in other words "import", is Toplumsal Cinsiyet Yanılsaması ${ }^{16}$ which is the translation of Delusions of Gender: How Our Minds, Society, and Neurosexism create Difference by Cordelia Fine. The book was translated by Kıvanç Tanrıyar, published in March 2011 and is placed under the series of "LGBT Kitaplığı".

${ }^{16}$ An explanation about this book is provided above. For further information, please visit https://www.selyayincilik.com/kitap/toplumsal-cinsiyet-yanilsamasi-707 
The book is a psychological and neurological study on the delusions of gender constructed in the society, and it was a bestseller in UK in 2010 (Sel Yayıncılık, 2016, para. 2). Tanrıyar is a translator, storywriter and an author. He publishes his stories on his blog at www.oykunmekleilgili.blogspot.com.tr. He wrote a book titled Aykırı Cinsellikler which was published by Ayrıntı Publishing House (Kidega, 2020, para. 2). He also wrote a number of pieces for Kaos GL. For instance, he wrote a piece about Toplumsal Cinsiyet Yanılması on the Kaos GL website in order to promote his translation (Tanriyar, 2011, para. 3). In the piece, he gave a brief introduction about the book and he mentions his name as the translator at the end of the text. Other than this mention, there was no indication that the book was translated and Tanryar did not give any information about the translation process. Tanriyar translated various books such as Sermayenin Mekanları (2012), Hatalıydım, Özür Diliyorum - Özürlerin Anlamları (2010) and Erken Dönem Osmanlı Devleti'nin Yapısı (2010). Furthermore, he also translated two other books in "LGBT Kitaplığı", namely Gay ve Lezbiyen Yazını (2011) and Cinsellik and Sosyalizm (2012). Gay ve Lezbiyen Yazını is the translation of Hugh Stevens' book The Cambridge Companion to Gay and Lesbian Writing and Cinsellik and Sosyalizm is the translation of Sexuality and Socialism by Sherry Wolf. The Cambridge Companion to Gay and Lesbian Writing can be described as a reference book that offers its readers information about the works of lesbian and gay writers, homosexual desire, and research on literary representations of queer identities whereas Sexuality and Socialism delves into the myths about sexuality and gender, the functions of social judgments on this subject and reveals the reason why capitalism constantly reproduces the man/woman dichotomy.

In addition to the Tanrıyar's piece, a review of Toplumsal Cinsiyet Yanılsaması was published in Sabitfikir, a prominent literary magazine in Turkey (Düzkan, 2011, p. 5). Düzkan gave information about the book and promoted it; however, she did not mention the fact that the book is a translation and thus, there was no information about the translator in the article. For the other translations of Tanriyar for Sel Publishing, most of the reviews mentioned his name as the translator but there was neither further information on him nor positive or negative comments on the translation.

Gay ve Lezbiyen Yazını was reviewed in newspaper supplements such as Agos Kitap (Erdal, 2011), Radikal Kitap (Öğüt, 2011, p. 14), and in the website of Kaos GL (Aydoğdu, 2011). Cihan Erdal's review in Agos Kitap comprehensively discusses the queer subjects that the book deals with. In the review, Tanriyar's name is mentioned as the translator but no further information about him, or the fact that the book is a translated text, is given. However, the text quotes the scarcity of Turkish resources on gay and lesbian literature and emphasizes the literary and social significance of the book (Erdal, 2011). Ögüt's review only mentions Tanrıyar as the translator whereas Aydoğdu's feature in Kaos GL includes the fact that the book is a translation from English into Turkish right from the beginning and deemed it as a good guidebook for 
academic and social research on homosexuality (Aydoğdu, 2011, para. 1). An İstanbulbased periodical Time Out Istanbul conducted an interview with İrfan Sancl, the owner of Sel Publishing after Gay ve Lezbiyen Yazını was published (Su, 2011, p. 206). The interviewer Su asks about the reason behind the decision to publish Gay ve Lezbiyen Yazını and interestingly she uses the verb "publish" instead of acknowledging the book as a translation by using the verb "translate". Sancı refers to the book as an important and informative reference book on lesbian and gay writers and their works, and mentions that both Gay ve Lezbiyen Yazını and Toplumsal Cinsiyet Yanılsaması are helpful for healthy gender discussions. More importantly, Sancı makes a statement about LGBT series and cites that "in the series, we will include theoretical research books as well as books that share certain experiences and fictional texts. We want the selected books to be functional and have an intellectually stimulating content, especially if it is a research $\operatorname{book}^{17}\left(\right.$ p. 206). Moreover, Lambdaistanbul ${ }^{18}$ held a meeting with both İrfan Sancı and Kıvanç Tanrıyar in 12 February 2012 (Lambdaistanbul, 2012, para. 1). In the announcement of the meeting, they indicated Tanriyar as the translator of the book and the fact that there would be a discussion and presentation about the book. The announcement also remarked that a discussion would be made with Sancl about his future plans regarding LGBT community (para. 1).

Cinsellik ve Sosyalizm was reviewed in Sol newspaper (Özlen, 2014, p. 8) and the abovementioned newspaper supplement Radikal Kitap (Öğüt, 2012, p. 5). In the additional feature of Sol newspaper, regarding the publication news and books, entitled Kitaplıktan, Özlen extensively discusses the content of the book as well as theoretical arguments of the writer Sherry Wolf. On the other hand, there is no discussion about the translator or the publishing house, only their names are cited (Özlen, 2014, p. 8). In Radikal Kitap, Öğüt (2012) mentions Tanrıyar's name as the translator and she announces that she likes "LGBT Kitaplı̆̆ı" series of Sel Publishing. Afterwards she criticizes the arguments in the book but does not discuss the translator and the publishing house further. The book was also read in Kosmos book club which is an istanbul-based book club. In the announcement of the book club meeting, brief information is given about the book but neither publishing house nor the translator is mentioned (Kosmos Kitap Klubü, 2013, para. 9).

The first book of "Queer Düş'ün" series is Queer Tahayyül which is a compilation edited by Sibel Yardımcı and Özlem Güçlü in February 2013. It is also worth mentioning that this is the first indigenous Turkish text published under this series, thus making it an "invention" according to Even-Zohar's approach. The book includes both translations and original texts written in Turkish. Sibel Yardımcı is a Professor at the Department of Sociology in Mimar Sinan Fine Arts University and she carried out many academic studies (iletişim Yayınları, 2014, para. 1). Additionally, she wrote two books

\footnotetext{
17 All translations are mine, unless otherwise stated.

${ }^{18}$ Founded in 1993, Lambdaistanbul is a Turkish LGBTI Solidarity Organization which became official in 2006.
} 
titled Küreselleşen İstanbul'da Bienal: Kentsel Değişim ve Festivalizm and Hacıyatmazı Devirmek: Neoliberal Pratiklere Karşı Kolektivite. She also translated the book entitled Öznellik ve Hakikat by Michel Foucault (Kitapyurdu.com). Özlem Güçlü is a faculty member of Department of Sociology in Mimar Sinan Fine Arts University and she is also the writer of three books: Female Silences, Turkey's Crises: Gender, Nation and Past in the New Cinema of Turkey (Yapı Kredi Yayınları, 2021, para. 1). Queer Tahayyül got reviews in a website named EdebiyatHaber.net (Egbatan, 2013, p. 4) and Birgün Kitap which is an additional feature of Birgün newspaper (Uzun, 2013, p. 13). In the website titled EdebiyatHaber.net which is dedicated to news in literature world, Egbatan gives the names of editors, mentions Sel Publishing and claims that the book offers a different reading of queer theory (Egbatan, 2013, para. 4). On the other hand, Uzun's piece in Birgün Kitap took Sel Publishing as centerfold and discusses three books in "Queer Düş'ün" series: Queer Tahayyül, Straight Düşünce and Çuvallamanın Queer Sanatı. Uzun mentions the editors Sibel Yardımcı and Özlem Güçlü of Queer Tahayyül and posits their statement about queer theory while introducing the book. The visibility of editors is different and the fact that the book is composed of different articles on different queer subjects is emphasized. Be that as it may, while introducing the other two "Queer Düş'ün” books Straight Düşünce and Çuvallamanın Queer Sanatı in the rest of the piece, the translators are only mentioned by name and no further information is given or no statements from the translators are given (Uzun, 2013, p. 13).

Straight Düşünce, written by Monique Wittig under the title of La Pensée Straight, is translated from French into Turkish by Leman Sevda Darıcıoğlu and Pınar Büyüktaş in May 2013. It is also noteworthy that this is the first translated text under the "Queer Düş'ün" series. Leman Sevda Darıcıoğlu is a performance artist, translator, activist and writer in Kaos GL (Darıcıoğlu, 2020, para. 1) and Pınar Büyüktaş is a translator and activist as she is a member of Kadının İnsan Hakları Derneği (Women for Women's Human Rights) in Turkey (Büyüktaş et al., 2016, p. 19). She also translated two more books: Feminist Bir Yaşam Sürmek by Sara Ahmed for Sel Publishing and Queer Marksizme Doğru by Kevin Floyd for NotaBene Publishing House (Kırmızı Kedi, 2016, para. 1). In addition to abovementioned review of Straight Düşünce, the book was reviewed in EdebiyatHaber.net (Egbatan, 2013) and Radikal Kitap (Ezber, 2015). Egbatan who previously reviewed Queer Tahayyül, signifies Straight Düşünce's importance by claiming, "the book proposes gender as a political category and criticizes social agreement on heterosexuality" (Egbatan, 2013, para. 1). Even though Egbatan comments on the style on Wittig and deemed it as hard-to-understand, she never mentions that the book is a translation and how the decisions taken by the translators might have affected Wittig's style. Moreover, Egbatan does not mention Sel Publishing once in her piece. On the other piece, Ezber (2015) discusses ten Turkish books, of which are both translations and original texts, about queer theory. Four of these books are published by Sel Publishing, namely Straight Düşünce, Queer Tahayyül, Çuvallamanın Queer Sanatı and Öteki Erkekler. Ezber briefly introduces every book in 
one paragraph, gives a short summary, yet, other than the names of publishing houses of each book, he does not mention any of the translators except for the editors of Queer Tahayyül. However, he expresses that every book is a significant contribution to Turkish repertoire on queer theory (p. 10).

Darıcıoğlu and Büyüktaş translated another book from French for "Queer Düş'ün" series in December 2016 and it is King Kong Teori whose original name is King Kong Théorie by Virginie Despentes. It is the most recent and last book published under the "Queer Düş'ün" series and it was promoted in EdebiyatHaber.net (EdebiyatHaber.net, 2016). The review mentions that the book is a translation published by Sel Publishing and the translators are Leman Sevda Darıcıoğlu and Pınar Büyüktaş right out of the gate. The book is defined in the review as "honest, brutal, clever and provocative" (para. 4). Yet, the contribution of this translation into Turkish nonliterary repertoire is not discussed.

Darıcıoğlu also edited a compilation titled Queer Temaşa in February 2016 and it was reviewed in KültüreServisi.com which is a website that defines itself as the cultural newspaper of Turkey (Kulakoğlu, 2016, para. 1) and Radikal Kitap (Ezber, 2016, p. 11). Kulakoğlu conducted an interview with the editor Darıcıoğlu and discussed her views on queer thought and queer subjects that are touched upon in the book. Darıcıoğlu describes the book as "a door for Queer" and states that the book covers various areas such as theory, daily life, art and activism (Kulakoğlu, 2016, para. 1). She does not specifically talk about the translational aspect of the book as well as the book's contribution to Turkish nonliterary repertoire. In the same vein, Ezber also mentions that Queer Temaşa was edited by Darıcıoğlu and published by Sel Publishing. Although Ezber does not underline the fact that the compilation is composed of both indigenous texts and translations, he describes the book as a valuable compilation that sheds a light on queer theory and offers the readers tangible and practical reflections of queer theory in life. He adds that the book is important in describing different types of queer life (Ezber, 2016, p. 11).

In October 2013, Sel Publishing published Çuvallamanın Queer Sanatı, originally titled as The Queer Art of Failure by Judith Halberstam, and it was translated by İpek Tabur who is a writer in a website called 5harfliler.com which focuses on the news about women and tackles the problems of women (Tabur, 2014, para. 1). She is also a translator and an editor (Boğaziçi Arşiv ve Dokümantasyon Merkezi, n.d.). As previously mentioned, Çuvallamanın Queer Sanatı, was reviewed by Uzun in Birgün Kitap (Uzun, 2013, p. 13) and Ezber in Radikal Kitap (Ezber, 2015). It was also reviewed in Kaos GL website (İzgi, 2016, para. 1). Interestingly, İzgi offers a lengthy summary of the book but never once mentions the translator, Sel Publishing or the fact that the book is a translation. It is also promoted in a blog written by Erkan Canan (2013, para. 1). The blogger cites the name of the translator and the publishing house but presents a very brief introductory text. 
Fetiş Ikame is another compilation published under the "Queer Düş'ün" series in December 2014 and edited by Tuna Erdem and Seda Ergül. Erdem is an artist and a translator (Kırmızı Kedi, 2016, para. 1) and Seda Ergül is an independent researcher and a translator (Ergül, 2021, para. 1). Both Erdem and Ergül are founding members of İstanbul Queer Art Collective which was founded to engage with live art and support queer performance art (İstanbul Queer Art Collective, 2019, para. 1). Fetiş ikame got reviews in Hürriyet (Çevik, 2014, p. 9), CnnTürk.com which is one of the mainstream news services of Turkey (CNNTürk.com, 2014, para. 4) and Tempo Kitap. Çevik's review is noteworthy in the sense that Hürriyet newspaper is a very well-known Turkish newspaper and thus, a coverage in that newspaper would have probably reached for a wider audience. Çevik (2014) mentions the names of both editors and the publishing house but not the fact that the book includes translations. Although there is no explanation about the contribution of this book to the Turkish nonliterary repertoire or Turkish queer community, he emphasizes the importance of this book two times. In CnnTürk website, Erdem and Ergül are cited as the editors of the book and Sel Publishing's name is also referred. Afterwards, a brief summary which is the same one in the Sel Publishing's website is given and the translations within the book are not mentioned. The piece is placed under the sub-section of "Book News" which is within the section called "Culture and Art News" (CNNTürk.com, 2014, para. 4). Tempo was a Turkish lifestyle magazine but it ceased publication in 2016. However, during the period of its publication life, it was both popular and at times controversial. Fetiş ikame is mentioned in a small section of the magazine in which they give brief information about newly published books. In that section, it is revealed that the book is published by Sel Publishing and a short summary of it was given. On the other hand, neither the editors nor the importance of the book within the Turkish nonliterary repertoire are mentioned. Moreover, the fact that the book also includes translations is not acknowledged (see Tempo Kitap, 2015).

The other two books in "Queer Düş'ün" were written by Sara Ahmed. The first one is Duyguların Kültürel Politikası originally named as The Cultural Politics of Emotion and translated by Sultan Komut in April 2015. The second one is Mutluluk Vaadi originally named as The Promise of Happiness and translated by Deniz Mayadağ in June 2016. Sultan Komut is a writer and her stories were published in various magazines such as Varlık, Dünyanın Öyküsü and Izafi. She is also an editor in Izafi magazine (Komut). She also wrote one book named Öte and she is the head of the Department of Translation and Interpreting in Haliç University as of May, 2021 (Haliç Üniversitesi, 2021, para. 1). Deniz Mayadağ is a professional translator and interpreter and worked as a subtitler and dubbing translator in many channels such as TNT, 24 Kitchen and DSmart (Mayadağ, 2021, para. 3). Duyguların Kültürel Politikası has been reviewed in various media outlets such as Kaos GL website (Kaos GL, 2015), Time Out Istanbul (Epik, 2015), Birgün Kitap (Temel, 2016, p. 17), and lastly Gaia Dergi which is a magazine that publishes news about ecology, women's rights, LGBT rights, human rights, culture and art (Elçik, 2016). Mutluluk Vaadi, on the other hand, got reviews in Evrensel which is a 
Turkish daily newspaper (Ceviz, 2016, p. 8) and GazeteDuvar.com which is a Turkish news website with a specific focus on literary news (Ezber, 2016, para. 2).

The first review of Duyguların Kültürel Politikası is in Kaos GL and it starts right away by declaring the fact that the book was rendered into Turkish by Sel Publishing and thus, acknowledging the fact that this book is a translation. It is also mentioned that the translation is published under the "Queer Düş'ün" series (Kaos GL, 2015, para. 2). This is a critical step towards the visibility of translator and the act of translation. Moreover, further in the text, the name of the translator is given, and it is mentioned that she translated the book from English into Turkish, which leaves no room for a confusion of whether this is a translation or not. Furthermore, Gülkan Noir who is the editor of Duyguların Kültürel Politikası made certain comments on the book, and her comments were included in the review (para. 3). There is no mention of the contribution of this translation into the Turkish but it is safe to say that the book has got a lot of exposure as a translation. In Time Out istanbul, Epik expresses that the book was published under the series of "Queer Düş'ün"; however, she does not give any further information about neither the translator nor the fact that the text is a translation. Furthermore, there is a brief summary of the book but no statement about the book's contribution to the Turkish literature repertoire (Epik, 2015). Temel makes a detailed analysis of the book in her review in Birgün Kitap. She gives the names of the translator and publishing house and nothing more, yet she does not comment on the influence of the book on Turkish nonliterary world (Temel, 2016, p. 17). Finally, the last mention of Duyguların Kültürel Politikası is in a piece by Elçik in Gaia Dergi. Elçik's piece is about pain and fear and it can be said that it is a think piece in which the writer talks about her experiences. Duyguların Kültürel Politikası is briefly mentioned in order to support the writer's claims on pain and there is no further information about the translator or the publishing house (Elçik, 2016).

Mutluluk Vaadi got two reviews. In Evrensel newspaper, Ceviz starts her review with these exact words: "Sara Ahmed's book Mutluluk Vaadi is added to Queer Düş'ün Series of Sel Publishingwith the translation of Deniz Mayadağ" (Ceviz, 2016, p. 8). Ceviz also states that Duyguların Kültürel Politikası by Sara Ahmed was published by Sel Publishing. She adds that this translation will fill a gap within the gender and women studies in Turkish. She also names the book as a reference book. In the other review in GazeteDuvar.com, Ezber gives a lengthy analysis of Ahmed's thoughts in the book, and states that the book provides a critical and questioning perspective (Ezber, 2016, para. 2). Yet the translator and the publishing house are not mentioned in anywhere, rather there is only a photo of the book cover that displays their names on it.

The last translated book under "LGBT Kitaplığı" series is Homofobi Sözlüğü (2018) which is originally titled as Dictionnaire de L'Homophobie and written by LouisGeorges Tin. The book is translated by Melis Tezkan and Okan Urun from French into Turkish. Tezkan and Urun are an artist duo that creates stage performances, 
installations and videos (Tezkan \& Urun, 2021, para. 1). Tezkan is an actress, director and writer and a guest lecturer in different universities both in Turkey and France (Tiyatrolar.com.tr, 2015, para. 1). Likewise, Urun is also an actor, writer, director and a guest lecturer at the Department of Fine Arts in Maltepe University (Tiyatrolar.com.tr, 2015, para. 1). The book got a number of reviews. In a website about the cultural news titled KültürServisi.com, Bulunmaz gives a historical background about the discriminations against LGBTI+ individuals and explains that the book is also about these issues. He briefly mentions the translators and the publishing house at the end of his review and does not give a clue about the book's influence on Turkish culture (Bulunmaz, 2018, para. 7). In Hürriyet.com.tr which is the website of one the most notable newspapers of Turkey, the book is defined as a must-have book for everybody, and a few aspects of the book are discussed. Like the abovementioned review, the information about the translators and the publishing house is given in a name base at the end of the text and no further information about them is provided (Türkölmez, 2018, para. 1). In T24 which is an independent Internet newspaper, Çimen (2018) starts by mentioning the fact that the book was published by Sel Publishing under the series of "LGBT Kitaplığı" and it was translated by Melis Tezkan and Okan Urun from French into Turkish (para. 2). Çimen also adds that the book is a very functional resource for enlightening the vital elements of old contemporary discussions even though it is not contemporary enough. He also thinks that it is a good source book to have (para. 2). Kaos GL website is another platform that includes a review on Homofobi Sözlüğü. Tar (2018) offers an extensive discussion of the book and he also mentions Sel Publishing as well as the fact that the book is a translation together with the names of translators (para. 2). He also comments on the translation by acknowledging the challenging nature of the translators' task and reveals that the translation is very clear and simple for target readers (para. 16). Finally, Tar defines the book as a cornerstone in revealing the homophobia that exists in every aspect of life. In MevzuEdebiyat.com which is an online platform about literature, Yıldırım (2018) reviews Homofobi Sözlüğü and describes the book as a guidebook that enlightens the dark sides of homophobia (para. 7). She briefly mentions the names of the translators and the publishing house at the end of the text, yet provides no further information about them. Last but not least, Altunay (2020) wrote a piece about the book in Matkap which is an art and literary magazine (para. 2). She mentions that the book is translated by Tezkan and Urun, and published by Sel Publishing at the beginning, and she ends the review with a statement that declares the book as an important reference book that might contribute to the fight against prejudices and homophobia (para. 7).

Öteki Erkekler by Aras Güngör (2013) and Göğe Kuşak Lazım by Ahmet Güneş (2016) are the first two indigenous books in "LGBT Kitaplığı". The former consists of the stories and experiences of 7 transgender women in Turkey and Radikal Kitap (Izzi, 2013, p. 23), Milliyet newspaper (Oral, 2013, pp. 22-23) and Git\&Yap magazine (Renay, 2013, p. 118) published interviews with Aras Güngör while Time Out Istanbul (Epik, 2013) and, again, Radikal Kitap (Ezber, 2013) published reviews on the book. On the 
other hand, Göğe Kuşak Lazım which narrates the queer history of Turkey got one review in Radikal Kitap by Ezber (2016, p. 13).

The first interview with Aras Güngör, writer of Öteki Erkekler is in Radikal Kitap and the interviewer İzci (2013) describes Güngör as a LGBT activist. She explains that the book focuses on the family lives, educations and health of transsexual men and their experiences of gender confirmation surgeries (p. 28). İzci does not forget to mention that the book is published by Sel Publishing. In the interview, Güngör who is a transgender man himself describes that the book came out of the need to discuss the stories of trans men in order to get one step closer for providing solutions for trans people's problems (p. 28). In another interview in Milliyet Sanat, a supplement of Milliyet newspaper, Güngör declares that this is the first Turkish book on trans men and that's why it is important (Oral, 2013, pp. 22-23). He also stated "I politically identify myself as trans man" (p. 23). Güngör tells his journey of becoming a man and points that the aim of the book is to reveal the existence, the demands and problems of trans men. Sel Publishing is also mentioned as the publishing house, but there is no further comment on it in the piece. In the other interview in Git\&Yap magazine, Güngör expresses that he wrote this book because he simply had to in order for trans men to be understood and included in the policy making process (Renay, İşte "Öteki Erkekler, 2013, p. 118). Sel Publishing is also mentioned as the publishing house in this piece. Epik's review in Time Out istanbul magazine offers a brief summary about the book and the writer but no information is given about the publishing house (Epik, 2013) while Ezber's review in Radikal Kitap express that the book is published by Sel Publishing under the series of "LGBT Kitaplığı" right at the beginning but does not discuss the publishing house any further (Ezber, 2013).

Göğe Kuşak Lazım is reviewed by Ezber (2016) and he gives brief information about the subject of the book and defines it as a documentary-like reference book about the history of LBGT movement in Turkey (p. 13). He mentions that the book is published by Sel under the "LGBT Kitaplığı" series and it is an important study on LGBT history of Turkey, a great contribution to Turkish nonliterary repertoire by the writer Ahmet Güneş. He does not discuss the writer further in detail (p. 13).

The most recent addition to "LGBT Kitaplığı" series is Ah Bu Sevda! - Türk Edebiyatında "Öteki" Cinsellik Öyküleri 1872-1928 (2020) by Serdar Soydan which is also an indigenous text in the series. In his book, Soydan tracks down the existence of "other" sexual identities in Turkish literature from the Tanzimat Reform Era to Atatürk's Reform of New Alphabet. The book is reviewed in Bant Mag which is an İstanbul based art, music and cinema magazine and two interviews are conducted with Soydan in Istanbul Life magazine and T24 newspaper. In the first review in Bant Mag, Geçer (2020) explaines that the book is published by Sel Publishing on Pride Month and defines the book as a queer perspective on Turkish literature (p. 1). In Istanbul Life magazine, Abik discusses the book with Soydan, and Sel Publishing only passes by 
name and is not discussed at length. It is noteworthy to mention that Soydan expresses that while he was trying to find his homosexual identity, he did not encounter texts on homosexuality and that was not easy on him during that process. That is why, he decided to search for "other" type of identities in Turkish literature (2020, p. 88). Finally, in T24 newspaper, Soydan is interviewed by Koloğlu, and he claims the aim of this book is to bring the other sexualities to the fore. Sel Publishing is only mentioned once by name throughout the interview (2020, para. 16).

\section{Discussion and Conclusion}

Inspired by agency concept of Anthony Giddens, one of the most prominent translation scholars, Lawrence Venuti (1996) states, "human action is intentional, but determinate, self-reflexively measured against social rules and resources, the heterogeneity of which allows for the possibility of change with every self-reflexive action" (p. 206). That is to say, every deliberate action of an agent is capable of social change. In line with this thought, Wolf (2007) explains that analyzing the social aspect of translation enables us to identify the translator as well as other agents of translation "as a constructing and constructed subject in society" (p. 1). To that end, the previous research on the translators and the publishing house carries the aim of revealing whether their intentional actions caused a social reaction and laid the foundation of a social change. The measure of the social reaction is taken as the reviews, interviews and critiques. Moreover, the acknowledgment of these translation agents in these epitexts has paramount importance in verifying their roles in social change. Furthermore, the emergence of indigenous texts written in the target language, which are the products of Turkish culture repertoire, is also a strong indicator of the social change.

Regarding the comprehensive amount of information above, it is safe to say that Sel Publishing made remarkable contributions to Turkish culture repertoire on queer nonliterary literature. Let us not forget that the selection process of the books to be published under these series is carried out by Sel Publishing. To be more specific, the decision on the texts whether a translation or an indigenous Turkish text belongs to the publishing house. This power as a decision maker certainly puts them into the position of "option maker". The nine books under these two series are translations and they can be categorized as "imports" which later turned into "transfers" as reviews and interviews demonstrate. In one of the interviews with Sel Publishing, Sancl claims that they observe a great interest in these series and the number of the readers of these books increases day by day (Alpar, 2019, p. 13). In another interview, he states that they always received the support of the readers about these publications of queer texts and never encountered any negative feedback about them (Serin \& Özlen, 2017, p. 14). Finally, while giving an interview about Gay ve Lezbiyen Yazını, Sancı claims that 
he is against any discrimination against LGBTI community (Su, 2011, p. 206). These books are even mentioned in advised reading lists of the Department of Women Studies in Ege University (Ege Üniversitesi, Kadın Çalışmaları Anabilim Dalı, 2016, para. 53) and the Women Studies Research Center in Karadeniz Technical University (Karadeniz Teknik Üniversitesi Kadın Araştırmaları Uygulama Araştırma Merkezi, 2016, para. 187) and this fact confirms the canonical importance of the books within Turkish nonliterary repertoire.

Öteki Erkekler, Göğe Kuşak Lazım and Ah Bu Sevda! - Türk Edebiyatında "Öteki" Cinsellik Öyküleri are the three indigenous texts that are written by Turkish authors in Turkish and they are about the queer history, queer literature and the experiences of queer identities in Turkey. Moreover, Queer Temaşa, Fetiş Ikâme and Queer Tahayyül are compilations that include a number of translated essays but more importantly, they offer essays written in Turkish about queer thought and queer individuals. The fact that these books include original texts which are produced in Turkish culture repertoire puts them under the same category with the three original texts above. Consequently, these six books can be deemed as "inventions" and they can be taken as another proof for the fact that the abovementioned "imports" are successfully integrated into Turkish culture repertoire and became "transfers". It is worth noting that the first three books that were published under the two series are Cinsellik ve Sosyalizm, Gey ve Lezbiyen Yazını, Toplumsal Cinsiyet Yanılsaması and they are translations, in other words "imports". It can be suggested that these six indigenous texts were produced after the three translations became "transfers" and thus, this fact supports the argument that defines the six books as "inventions".

Finally, it is safe to say that the claim of this study regarding Sel Publishing as a cultural agent that introduces queer theory into Turkey is confirmed. The fact that they accepted their contributions to the literature can be taken as a solid evidence for its agency. What sets apart Sel Publishing from other publishing houses is that it publishes selected works on queer thought in a systematic way as two separate book series that carry the names of "LGBT" and "Queer" in their titles. This certainly provides visibility for queer theory and thought to a certain extent. Additionally, the fact that, at first, these two series started with translations and then, these translations paved the way for the production of indigenous Turkish texts on queer thought and theory displays how they achieved the introduction of queer theory into Turkish nonliterary repertoire.

This present study carries out a sociological analysis on Sel Publishing in order to determine its position as a cultural agent in Turkish culture repertoire. This sociological study is conducted by exploring the social position of the publishing house and the translators. Subsequently, in order to determine the "receptive attitude" of the target repertoire, in other words, "the willingness of specific agencies in a culture to adopt what is viewed as an external repertoire" (Sela-Sheffy, 2003, p. 5), the interviews, reviews and critiques on the books under these two series are analyzed. By 
so doing, the history of queer studies in the world and in Turkey and the Turkish culture repertoire on queer studies are mapped out and discussed. Finally, it is demonstrated that Sel Publishing holds a certain power due to being a forerunner about the publications on queer theory.

This study also displays the urgent need for more queer translation studies in Turkey. Evidently, the scarcity of queer studies in Turkey stems from the fact that Queer Studies is a relatively new field of study in this country. This leads us to the conclusion that there is also a great need for queer studies within the Turkish context. Such studies will also serve and provide great benefit for queer community in Turkey by making them more visible and helping them to become less marginalized in Turkish society. It can be suggested that Sel Publishing serves this purpose with these two series by making them seem more visible and less marginal in the eyes of Turkish society. All in all, it can be suggested that Sel Publishing has made significant contributions to the queer studies and queer community.

\section{References}

Abik, B. (2020, August 1). Nerdesin aşkım? Tanzimat dönemindeyim aşkım. İstanbul Life . https://istanbullife.com.tr/roportajlar/nerdesin-askim-tanzimat-donemindeyim-askim/

Acar, T. (2002, June 25). Bankacı cinayetini disketler çözecek. Sabah Gazetesi. http://web.archive.org/web/20140427010738/http://arsiv.sabah.com.tr/2002/06/25/s0 306.html

Aciman, S. (2002). Bella. Galata.

Ahmed, S. (2015). Duyguların kültürel politikası (S. Komut, Trans.) Sel Yayıncılık. (Original work published 2004)

Ahmed, S. (2016). Mutluluk vaadi. (D. Mayadağ, Trans.) Sel Yayıncılık. (Original work published 2010)

Akgün, A. (2019). Kentsel hareketlilikte queer kimliğin gündelik yaşam pratikleri [Unpublished master's thesis], İstanbul Technical University.

Aksoy, Z. (2003). Deniz kızı. An Yayıncılık.

Aktaş, G. B. (2019). Bağımsız grafik romanda queer eylem [Unpublished master's thesis], Yaşar University.

Albayrak, G. (2009). Gender and sexuality in three British plays: Cloud Nine by Caryl Churchill My Beautiful Laundrette by Hanif Kureishi, The Invention of Love by Tom Stoppard [Unpublished master's thesis], Middle East Technical University.

Alpar, A. (2019, February 11). Türkiye'de queer yayıncılık: Sel yayıncılık anlatıyor. Retrieved June 3, 2021, from Kaos GL.

https://kaosgl.org/haber/turkiyede-queer-yayincilik-sel-yayincilik-anlatiyor 
Alsamua, M. (2019). Queer sinemada atmosfer yaratımı [Unpublished master's thesis], Eskişehir Osmangazi University.

Altıoklar, M., Kaçan, M. (Writers), \& Altıoklar, M. (Director). (1997). Ağır roman [Motion Picture]. Turkey, Hungary, France: Özen Film.

Altay, M. T. (2019). Negotiating community engagements and alliances: Queer people of color and Turkish migrants in Berlin [Unpublished master's thesis], Boğaziçi University.

Altunay, A. (2020, August 10). Özgürleşme mücadelesinde "Homofobi Sözlüğü". Retrieved February 4, 2021, from Matkap Sanat Edebiyat. https://www.matkapdergisi.com/post/ozgurlesme-mucadelesinde-homofobi-sozlugu

Altunpolat, R. (2013, December 17). Saklananlar ve söylenenler: Türk romanında LGBT kimliklerin yol izleri. Retrieved May 24, 2021, from Kaos GL.

https://kaosgl.org/gokkusagi-forumu-kose-yazisi/saklananlar-ve-soylenenler-turkromaninda-lgbt-kimliklerin-yol-izleri

Asena, D. (2004). Paramparça. Doğan Kitap.

Ataman, K., Mağden, P. (Writers), \& Ataman, K. (Director). (2005). iki genç kız [Motion Picture]. Turkey.

Aydan, E., Bayülgen, O., Rico, B., Ay, S., Olcay, Z., Bilginer Haluk, et al. (Producers), Altıoklar, M. (Writer), \& Altıoklar, M. (Director). (1996). Istanbul kanatlarımın altında [Motion Picture]. Turkey: Umut Sanat.

Aydoğdu, G. (2011, December 30). lyi bir rehber: "Gey ve lezbiyen yazını". Retrieved January 19, 2017, from Kaos GL: http://www.kaosgl.com/sayfa.php?id=10242

Baer, B. J. (2014). Interpreting Daniel Stein: Or what happens when fictional translators get translated? In K. Kaindl, \& K. Spitzl (Eds.), Transfiction: Research into the realities of translation fiction (pp. 157-175). John Benjamins.

Baer, B. J. (2020). Queer theory and translation studies: Language, politics, desire. Routledge.

Baer, B. J. (2011). Translating queer texts in Soviet Russia: A case study in productive censorship. Translation Studies , 4(1), 21-40.

Baer, B., \& Kaindl, K. (Eds.). (2018). Queering translation, translating the queer: Theory, practice, activism. Routledge.

Baird, V. (2004). Cinsel çeşitlilik: Yönelimler, politikalar, haklar ve ihlaller (H. Doğan, Trans). Metis Yayıncılık. (Original work published 2001)

Balkan, C. (2016). Istanbul'un dışlanma mekânları: Cinsiyet odaklı altkültür incelemesi ve altkültürün kent parçaları ile ilişkisi [Unpublished master's thesis], İstanbul Technical University, Department of Architecture.

Bardakçı, M. (2006, August 27). 'Gay'ler eskiden esnaftan sayılır ve padişahın huzurunda yapılan resmi geçitlere bile katılırlardı. Hürriyet. 
http://www.hurriyet.com.tr/gay-ler-eskiden-esnaftan-sayilir-ve-padisahin-huzurundayapilan-resmigecitlere-bile-katilirlardi-4985167

Bastin, G. L. (2009). Francisco de Miranda, Intercultural Forerunner. In J. Milton, \& P. Banndia (Eds.), Agents of translation (pp. 19-42). John Benjamins.

BIA News Center. (2014, April 22). Beyoğlu'nda Trans Cinayeti. Retrieved January 17, 2017, from Bianet.

http://web.archive.org/web/20150702045651/http://www.bianet.org/bianet/lgbti/1551 43-beyoglu-nda-trans-cinayeti

Bilal, M. (2003). Üçüncü tekil şahıs. Everest Yayınları.

Black, J. (2008, July 19). Was Ahmet Yildiz the victim of Turkey's first gay honour killing? The Independent.

http://web.archive.org/web/20080818025816/http://www.independent.co.uk/news/w orld/europe/was-ahmet-yildiz-the-victim-of-turkeys-first-gay-honour-killing-871822.html

Boğaziçi Arşiv ve Dokümantasyon Merkezi. (n.d.). Hakkımızda. Retrieved February 4, 2021, from Boğaziçi University. http://arsivmerkezi.boun.edu.tr/about.php

Bolat, D. (2013). Türkiye muhalefet alanı ve heteroseksizm:Muhalefet alanında heteroseksüel olmamak [Unpublished master's thesis], Muğla Sıtkı Koçman University, Department of Sociology.

Branch, M. A. (1986). Back in the Fold. Retrieved January 16, 2017, from Yale Alumni Magazine. http://archives.yalealumnimagazine.com/issues/03_04/kramer.html

Bulunmaz, A. (2018, June 17). LGBTi+ bireylere yönelik 'kolektif şiddet sözlüğ̈̈'. Retrieved February 4, 2021, from Kültur servisi.

https://www.kulturservisi.com/p/lgbti-bireylere-yonelik-kolektif-siddet-sozlugu/

Burroughs, W. S. (2012). Queer (B. Denizci, Trans.). Altıkırkbeş Yayınları. (Original work published 1985)

Butler, J. (2014). Bela bedenler. (C. Çakırlar, \& Z. Talay, Trans.) Pinhan Yayıncılık. (Original work published 1996)

Butler, J. (2008/2016). Cinsiyet belası. (B. Ertür, Trans.) Metis Yayıncılık. (Original work published 1990)

Butler, J. (1990). Gender trouble: Feminism and the subversion of identity. Routledge.

Buzelin, H. (2011). Agents of translation. In Y. Gambier, \& L. Doorslaer (Eds.), Handbook of translation studies, Vol. 2 (pp. 6-12). John Benjamins.

Büyüközer, A. (2018). Zenne, Laurance anyways ve Something must break filmlerinin kuir teoriye göre yorumlanması [Unpublished master's thesis], Yaşar University.

Büyüktaş, P., Kıymaz Bahçeci, Ş., \& Erkan Yetişer, Y. (2016, July 25). Türkiye'nin kadın haklarına dair önemli iki haftası. Retrieved May 30, 2021, from Bianet.

http://bianet.org/yazar/pinar-buyuktas?sec=bianet 
Cabadağ, N. (2016). Negotiating queer public visibility: Experiences of LGBTI residents in Kurtuluş, Istanbul [Unpublished master's thesis], Sabancı University, Department of Cultural Studies.

Canan, E. (2013, November 19). Judith Halberstam - Çuvallamanın queer sanatı (2013). Retrieved January 31, 2021, from Dipnotski.

https://dipnotski.com/2013/11/19/judith-halberstam-cuvallamanin-queer-sanati-2013/

Candemir, D. M. (2016). 2000 sonrası Türkiye sinemasında queer imkanlar: Benim Çocuğum, Zenne ve Bizim Büyük Çaresizliğimiz üzerine bir çözümleme [Unpublished master's thesis], Anadolu University, Department of Cinema and Television.

Ceviz, K. (2016, August 1). Mutluluk nerede? Evrensel. https://www.evrensel.net/haber/286495/mutluluk-nerede

Chesterman, A. (2007). Bridge concepts in translation sociology. In M. Wolf, \& A. Fukari (Eds.), Constructing a sociology of translation (pp. 171-183). John Benjamins.

CNNTürk.com. (2014, December 12). Ayrıntı Yayınları ve Sel Yayıncılık Aralık ayı kitapları. http://www.cnnturk.com/haber/kultur-sanat/kitap/ayrinti-yayinlari-ve-sel-yayincilikaralik-ayi-kitaplari

Çakırlar, C., \& Delice, S. (Eds.). (2012). Cinsellik muamması: Türkiye'de queer ve muhalefet. Metis Yayınları.

Çalışkan, D. (2014). Queer mothers and daughters: The role of queer kinship in the everyday lives of trans sex worker women in Istanbul [Unpublished master's thesis], Sabancı University, Department of Cultural Studies.

Çetin, Ç. (2013). Why have there been no men artists? Analyzing awareness of masculinities through the artworks of "men" artists post 1990 in Turkey. Unpublished MA Thesis, Sabancı University, Department of Visual Arts and Visual Communication Design, İstanbul.

Çetin, K. (2021). Queer teori eleştirisi ve LGBT+ bireylerin queer teoriye yaklaşımı [Unpublished master's thesis], Ankara University.

Çevik, Ç. (2014, December 29). Haftanın kitapları. Hürriyet. https://www.hurriyet.com.tr/yazarlar/caglayan-cevik/haftanin-kitaplari-27855124

Çimen, T. O. (2018, July 12). Her türlü cinsel varoluşa karşı güdülen ve uygulanan şiddet edimleriyle mücadele etmek için: Homofobi sözlüğü. Retrieved February 4, 2021, from T24. https://t24.com.tr/k24/kitap/homofobi-sozlugu,293

Darıcıoğlu, L. S. (2020). About- Leman Sevda Darıcıoğlu. Retrieved February 4, 2021, from Leman S. Darıcıoğlu. http://lemandaricioglu.com/about/

Darıcıoğlu, L. S. (Ed.). (2016). Queer temaşa. Sel Yayıncılık.

Demiral, A. (2017). Biyoiktidar bağlamında; Toplumsal cinsiyet, Queer Teori ve sanata yansımaları [Unpublished master's thesis], Hacettepe University. 
Demircioğlu, C. (2009). Translating Europe: The case of Ahmed Midhat as an ottoman agent of translation. In J. Milton, \& P. Bandia (Eds.), Agents of Translation (pp. 131-160). John Benjamins.

Demirel, Ö. (2019). Kutluğ Ataman filmlerinde queer oluşlar: Lola ve Bilidikid ve iki Genç Kız üzerine bir okuma [Unpublished master's thesis], Muğla Sıtkı Koçman University.

Despentes, V. (2016). King Kong teori. (L. Darıcıoğlu, \& P. Büyüktaş, Trans.): Sel Yayıncılık. (Original work published 2006)

Doğan, i. T. (2016). Toplumsal cinsiyet rolleri bakımından 1990 sonrası Türk sinemasında eşcinsellik [Unpublished master's thesis], Dokuz Eylül University, Department of Cinema and Television.

Doğaner, H. S. (1992). Leyla ile Şirin. Varlık.

Dr. Ozlem Guclu. (n.d.). Retrieved January 19, 2017, from SOAS University of London. https://soas.ac.uk/staff/staff90360.php

Duman, Ç. Ö. (2020). HIV/AIDS in American theatre: Queerness, spatio-temporalities, and emancipation [Unpublished master's thesis], Boğaziçi University.

Düzkan, A. (2011, September 15). Bir cinsiyet durumu olarak Bukowski. Retrieved January 19, 2017, from Sabitfikir. http://sabitfikir.com/elestiri/bir-cinsiyet-durumu-olarak-bukowski

EdebiyatHaber.net. (2016, December 9). Virginie Despentes'ten bir feminizm manifestosu: “King Kong Teori" - See more at: http://www.edebiyathaber.net/virginie-despentesten-birfeminizm-manifestosu-king-kong-teori/\#sthash.HNVFyYHk.dpuf.

http://www.edebiyathaber.net/virginie-despentesten-bir-feminizm-manifestosu-kingkong-teori/

Egbatan, M. (2013, May 8). "Queer tahayyül": Dünyanın bütün kimlikleri oynaşınız! Retrieved January 31, 2021, Edebiyat Haber.

http://www.edebiyathaber.net/queer-tahayyul-dunyanin-butun-kimlikleri-oynasinizmine-egbatan/

Egbatan, M. (2013, July 20). "Straight düşünce": Heteroseksüel kalıplardan sıyrılmak. Retrieved January 19, 2017, from Edebiyat Haber.

http://www.edebiyathaber.net/straight-dusunce-heteroseksuel-kaliplardan-siyrilmakmine-egbatan/

Ege Üniversitesi, Kadın Çalışmaları Anabilim Dalı. (2016). Okuma listesi. Retrieved January 19, 2017, from Sosyal Bilimler Enstitüsü Kadın Çalışmaları Anabilim Dalı http://kadincalismalari.ege.edu.tr/d-699/OkumaListesi.html

Elçik, N. (2016, May 14). Gökyüzü politikası: Acı ve korku. Gaia Dergi. https://gaiadergi.com/gokyuzu-politikasi-aci-ve-korku/

Enderunlu Fazil. (2009). Güzel Oğlanlar Kitabı. Sel Yayıncılık.

Epik, S. (2015, August 8). Duyguların kültürel politikası. Time Out istanbul. https://www.selyayincilik.com/basin/DKP4.jpg 
Epik, S. (2013, July 31). İki kere öteki: Önce kadın sonra trans. Time Out istanbul. https://www.selyayincilik.com/basin/otekierkekler_timeout.jpg

Epstein, B., \& Gillett, R. (Eds.). (2017). Queer in translation. Routledge.

Erdal, C. (2011, December). Eşcinsel aşkın edebi hali. Agos Kitap. http://www.agos.com.tr/tr/yazi/245/escinsel-askin-edeb-hali

Erdem, T., \& Ergül, S. (Eds.). (2014). Fetiş ikâme. Sel Yayıncılık.

Erdoğan, A. (2020). Cinsel kimliklerin ötesinde: Queer hukuk kuramı [Unpublished master's thesis], İstanbul Kültür University.

Ergül, S. (2021). Seda Ergül. Retrieved June 8, 2021, from Academia https://independent.academia.edu/sedaergul

Ertetik, i. (2010). Coming out as a political act in lgbt movement in Turkey [Unpublished doctoral dissertation], Middle Eastern Technical University, Department of Sociology.

Even-Zohar, I. (2002). The making of culture repetoire and the role of transfer. In S. Paker (Ed.), translations: (re)shaping of literature and culture (pp. 351-359). Boğaziçi University Press.

Ezber, G. (2013, August 23). Görünmezliğin kıyısında. Radikal Kitap. https://www.selyayincilik.com/basin/otekierkekler-radikal.jpg

Ezber, G. (2015, November 18). On kitapta queer kuram. Radikal Kitap, p. 10.

Ezber, G. (2016, August 11). Mutluluk mutlu eder mi? Retrieved January 19, 2017, from Gazete Duvar. http://www.gazeteduvar.com.tr/kitap/2016/08/11/mutluluk-mutlu-eder-mi/

Ezber, G. (2016, March 18). Queer Hayat Nasıl Olur. Radikal Kitap, p. 11.

Ezber, G. (2016, May 6). Tabutluktan Bugünlere. Radikal Kitap, p. 13.

Fine, C. (2010). Delusions of gender: How our minds, society, and neurosexism create difference. W. W. Norton \& Company.

Fine, C. (2011). Toplumsal cinsiyet yanılsaması (K. Tanrıyar, Trans.). Sel Yayıncılık. (Original work published 2006)

Flotow, L. v. (1999). Genders and the translated text: Developments in 'transformance'. Textus XII, 275-288.

Flotow, L. v. (2012). Translating women: From recent histories and retranslations to 'queerying' translation, and metamorphosis. Quaderns. Revista de Traduccio, 19, 127-139.

Fryer, D. (2010). Thinking queerly: Race, sex, gender, and the ethics of identity. Routledge.

Geçer, M. Ç. (2020, June 22). Türkçe edebiyata kuir bakış: "Ah Bu Sevda!”. Retrieved February 4, 2021, from Bantmag. https://bantmag.com/turkce-edebiyata-kuir-bakis-ah-bu-sevda/

Gelibolulu Mustafa Ali. (1978). Görgü ve Toplum Kuralları Üzerinde Ziyafet Sofraları (Mevâidü'nnefâis fí Kavîdi'l Mecâlis). Tercüman Gazetesi. 
Gülhaş, A. (2020). Kuir perspektif: Mimarlığın çözüm problemi [Unpublished master's thesis], İstanbul Technical University.

Güneş, A. (2016). Göğe kuşak lazım. Sel Yayıncılık.

Güney, Ö. (2018). Queering teacher education programs: Perceptions of pre-service efl teachers towards queer issues [Unpublished master's thesis], İhsan Doğramacı Bilkent University.

Güngör, A. (2013). Öteki erkekler. Sel Yayıncılık.

Hacıoğlu, M. (Ed.). (2003). Eşcinsel kadınlar: Yirmi dört tanıklık. Metis Yayıncılık.

Halberstam, J. (2013). Çuvallamanın queer sanatı. (i. Tabur, Trans.) Sel Yayıncılık. (Original work published 2011)

Halberstam, J. (2005). In a queer time and place. New York University Press.

Haliç Üniversitesi. (2021). Akademik Kadro. Retrieved February 4, 2021, from Haliç Üniversitesi. http://fenedebiyat.halic.edu.tr/tr/bolumler/akademik-kadro/ingilizce-mutercimtercumanlik

Hamamcıoğlu, G. (2020). Gesturing toward utopia: Queer time and place in the performance art of Cassils, Boychild and Marval A Rex [Unpublished master's thesis], İhsan Doğramacı Bilkent University.

Harvey, K. (1998). Translating camp talk. The Translator, 4(2), 295320. DOI: 10.1080/13556509.1998.10799024

Harvey, K. (2000a). Decribing camp talk: Language/pragmatics/politics. Language and Literature, 9(3), 240-260.

Harvey, K. (2000b). Gay community, gay identity and the translated text. TTR, 13, 137-165.

Harvey, K. (2000c). Translating camp talk: Gay identities and cultural transfer. In L. Venuti (Ed.), The Translation Studies Reader (pp. 446-467). Routledge.

Harvey, K. (2003a). 'Events' and 'horizons': Reading ideology in the 'bindings' of translations. In M. Perez (Ed.), Apropos of ideology (pp. 43-69). St. Jerome.

Harvey, K. (2003b). Intercultural movements: American gay in French translation. St. Jerome.

Harvey, K., \& Shalom, C. (Eds.). (1997). Language and desire: Encoding sex, romance and intimacy. Routledge.

Hazar, C. (2012). Heteronormatif kimliklerin anlamlandırılma süreçleri: Türkiye'de kuir bireyler [Unpublished master's thesis], İstanbul University, Department of Gender Studies.

Hür, A. (2013, October 10). 'Elinde tesbih, evinde oğlan, dudağında dua...'. Retrieved October 16, 2020, from Radikal. http://www.radikal.com.tr/yazarlar/ayse-hur/elinde-tesbih-evindeoglan-dudaginda-dua-1159964/

İs, S. M. (2013). Tracking the invisible: Queer approaches to parenthood and family in Turkey [Unpublished master's thesis], Sabancı University, Department of Cultural Studies.

İleri, S. (1977). Her gece Bodrum. Altın Kitaplar. 
Illetişim Yayınları. (2014). Sibel Yardımcı. Retrieved January 19, 2017, from http://www.iletisim.com.tr/kisi/sibel-yardimci/7627\#.WIHmt2R94fE

İlhan, A. (Writer), \& Arakon, A. (Director). (1962). Ver elini Istanbul [Motion Picture]. Turkey: Acar Film.

İlhan, A. (1980). Fena Halde Leman. Türkiye İş Bankası Kültür Yayınları.

İlhan, A. (1981). Dersaadette Sabah Ezanları. Bilgi Yayınevi

İlhan, A. (1984). Haco Hanım Vay. Altın Kitaplar.

İmançer, Ç. E. (2018). Queer teorinin izinde Avrupalı bir Türk: Ferzan Özpetek ve sineması [Unpublished master's thesis], Selçuk University.

İstanbul Queer Art Collective. (2019). Bio. Retrieved February 4, 2021, from Istanbul Queer Art Collective. https://www.istanbulqueerartcollective.co.uk/bio

İzci, ì. (2013, July 3). Hem görünür hem görünmez: Trans erkekler. Radikal Kitap, p. 23.

İzgi, E. (2016, October 27). Ormanlara karşı ağaçları savunmak: Çuvallamanın queer sanatı. Retrieved January 31, 2021, from Kaos GL.

https://kaosgl.org/haber/ormanlara-karsi-agaclari-savunmak-cuvallamanin-queer-sanati

Jagose, A. (2015). Queer teori: Bir giriş. (A. Toprak, Trans.). Notabene Yayıncılık. (Original work published 1996)

Jagose, A. (1996). Queer theory: An introduction. New York University Press.

KAOS GL Dergisi. (n.d.). Dergi tanıtım. Retrieved May 29, 2021, Kaos GL dergi. https://www.kaosgldergi.com/hakkimizda/dergi-tanitim

KAOS GL Derneği. (2020). Biz Kimiz ? Retrieved June 8, 2021, from Kaos GL derneği. https://kaosgldernegi.org/hakkimizda/biz-kimiz

KAOS GL. (2013, May 30). Eşcinsellerin hakkını heteroseksüellerin savunduğu zaman Türkiye başka bir ülke olacak! Retrieved January 15, 2017, from KAOS GL haber portalı. http://kaosgl.org/sayfa.php?id=14254

Kaos GL. (2019, April 3). "Queer Düş'ündük, veda ediyoruz". Retrieved from Kaos GL. https://kaosgl.org/haber/queer-dusunduk-veda-ediyoruz

KAOS GL Kadın Grubu. (2009). Aşkın L hali. Sel Yayıncılık.

Kaos GL. (2015, April 2). Queer Düş'ün'den Sara Ahmed kitabı: Duyguların kültürel politikası. Retrieved May 30, 2021, from Kaos GL.

https://kaosgl.org/haber/queer-dusrsquounrsquoden-sara-ahmed-kitabi-duygularinkulturel-politikasi

Karadeniz Teknik Üniversitesi Kadın Araştırmaları Uygulama Araştırma Merkezi. (2016, June 23). Kadın ve Toplumsal Cinsiyet Konulu Kitaplar. Retrieved January 19, 2017, from http://www.ktu.edu.tr/kadinarastirmalari-kadinvetoplumsalcinsiyetkonulukitaplar 
Karalı, Ş. N. (2015). Türkiye'de sahnelenen yerli oyunlarda transseksüellik ve transfobi, [Unpublished master's thesis], Bahçeşehir University, Department of Advanced Acting.

Karasu, B. (1990). Kılavuz. Metis Yayıları.

Kaymaz, S. (2014a). Deccal'in hatırı. İletişim Yayıncılık.

Kaymaz, S. (2014b). Kısas. İletişim Yayıncılık.

Kaymaz, S. (2021). Son şura. Illetişim Yayıncılık.

Keniş, Ş. (2012). Islam and homosexuality debates in Turkey: Discursive contestation among muslims over LGBTQ rights [Unpublished master's thesis], Koç University.

Kılıç, H. D. (2018). The changing of portrayals of gay and queer identities in Julian Mitchell's another country, Jonathan Harvey's Beautiful Thing and Mark Ravenhill's Mother Clap's Molly House [Unpublished doctoral dissertation], Hacettepe University.

Kırmızı Kedi. (2016). Pınar Büyüktaş. Retrieved February 4, 2021, from Kırmızı Kedi. https://www.kirmizikedi.com/kitap/kisi/37897?o=0

Kırmızı Kedi. (2016). Tuna Erdem. Retrieved February 4, 2021, from Kırmızı Kedi. https://www.kirmizikedi.com/kitap/kisi/45805?o=0

Kırmızıgül, M. (Writer), \& Kırmızıgül, M. (Director). (2009). Güneşi gördüm [Motion Picture]. Turkey: Pinema.

Kidega. (2020). Kıvanç Tanrıyar biyografisi. Retrieved February 3, 2021, from Kidega. https://kidega.com/yazar/kivanc-tanriyar-188758

Kitapyurdu.com. (n.d.). Sibel Yardımcı. Retrieved February 1, 2021, from Kitap Yurdu. https://www.kitapyurdu.com/yazar/sibel-yardimci/31958.html

Koloğlu, D. (2020, September 30). Serdar Soydan: "Kendimizi bir şekilde var etmek ve tanımak için başka deneyimlere muhtacız". Retrieved February 4, 2021, from t24. https://t24.com.tr/k24/yazi/serdar-soydan-kendimizi-bir-sekilde-var-etmek-ve-tanimakicin-baska-deneyimlere-muhtaciz,2876

Komut, S. (n.d.). Sultan komut. Retrieved May 30, 2021, from Edebiyat haber. http://www.edebiyathaber.net/sultan-komut/

Korat, G. (2014). Yine doğdu tanyıldızı. Yapı Kredi Yayınları.

Koskinen, K. (2008). Translating institutions: An ethnographic study of EU translation. St. Jerome Publishing.

Kosmos Kitap Klubü. (2013, December 21). Okuduklarımız. Retrieved January 19, 2017, from http://www.kosmoskitap.org/okuduklar305m305z.html

Kulakoğlu, N. (2016, March 16). 'Nefes alacak bir alan yaratmak için: Queer temaşa'. Retrieved January 19, 2017, from Kültür Servisi. http://kulturservisi.com/p/nefes-alacak-bir-alanyaratmak-icin-queer-temasa

Kulin, A. (2002). Iki Genç Kızın Romanı. Doğan Kitap. 
Kulin, A. (2012). Bora'nın kitabı. Everest Yayınları.

Kulin, A. (2011). Gizli anların yolcusu. Everest Yayınları.

Kunt, M. E. (2013). Yeni Türk sineması'nda erillik bağlamında dişilliğin inşası. [Unpublished master's thesis], Marmara University, Department of Radio and Television.

Küçükvatan, S. (2019). Queer müslümanlarda dinî bireycilik [Unpublished master's thesis], Dokuz Eylül University.

Lambdaistanbul. (2012, February 12). Edebiyat ve LGBT: Sel yayınları LGBT dizisi ve "Gey ve lezbiyen yazını". Retrieved January 19, 2017, from http://www.lambdaistanbul.org/s/etkinlik/edebiyat-ve-lgbt-sel-yayinlari-lgbt-dizisi-ve"gey-ve-lezbiyen-yazini"/

Larkosh, C. (2007). Forms of a-dress: Performances of the foreign and s-other-n flows of transnational identity. Social Dynamics , 33(2), 164-183.

Larkosh, C. (2006). Migrant sexuality and translation of the self in Manuel Puig's later work. The Translator , 12(2), 279-299.

Larkosh, C. (Ed.). (2011). Re-engendering translation: Transcultural practice, gender/sexuality and the politics of alterity. St. Jerome.

Larkosh, C. (2007). The translator's closet: Editing identites in Argentine literary culture. TTR, 21(2), 63-88.

Levent, H. Y. (2015). Toplumsal cinsiyet bağlamında erkeklik; Gaziantep örneği [Unpublished master's thesis], Gaziantep University, Department of Sociology.

LGBT Kitaplığı. (2016). Retrieved January 18, 2017, from Sel Yayıncılık. http://www.selyayincilik.com/kitaplar/lgbt-kitapligi/

LGBTHaber. (2016, August 4). Eşcinseller Sel Yayıncılığı neden seviyor? Retrieved January 19, 2017, from

http://www.Igbthaber.net/2016/08/04/escniseller-sel-yayinciligi-neden-seviyor/

Livaneli, Z. (2016). Kardeşimin hikayesi. Doğan Kitap.

Mağden, P. (2002). iki genç kızın romanı. Doğan Kitap.

Mağden, P. (2010). Ali ile Ramazan. Doğan Kitap.

Mayadağ, D. (2021). Deniz Mayadağ. Retrieved June 8, 2021, from Linkedln. https://tr.linkedin.com/in/deniz-mayadag-763648a6

Milton, J., \& Bandia, P. (2009). Introduction: agents of translation and translation studies. In J. Milton, \& P. Bandia (Eds.), Agents of translation (pp. 1-18). John Benjamins.

Mungan, M. (1985). Son istanbul. Metis Yayınları.

Mutlu, E. (2012). Something queer in Istiklal [Unpublished master's thesis], Kadir Has University, Department of Sociology. 
Öğüt, H. (2011, December 19). Eşcinsel edebiyatından transgender politikalarına. Radikal Kitap , p. 14.

Öğüt, H. (2012, May 4). Marksizm, LGBT ve antifeminizm. Retrieved January 19, 2017, from Radikal kitap.

http://kitap.radikal.com.tr/makale/haber/marksizm_lgbt_ve_antifeminizm-62668

Oral, S. (2013, July 1). "Bacak arasında ne var" sorusu yanlış. Milliyet sanat, pp. 22-23.

Orhan Küzeci, P. (2003). Kurtlu elma şekeri. BRC Ofset.

Özbay, C. (2005). Virilities for rent: Navigating masculinity, sexuality, and class in istanbul [Unpublished master's thesis], Boğaziçi University, Department of Sociology.

Özbay, C., \& Soydan, S. (Eds.). (2002). Eşcinsel erkekler: Yirmi beş tanıklık. Metis Yayınları.

Özer, E. (2005). Queering the yuppie: Identity and performativity in Ally McBeal [Unpublished master's thesis], Hacettepe University.

Özlen, T. (2014, May 29). Marksistler homofobik midir? Cinsellik ve sosyalizm. Kitaplıktan - Sol gazetesi kitap eki, p. 8.

Özpetek, F., Tummolini, S., Sambrell, A. (Writers), \& Özpetek, F. (Director). (1997). Hamam [Motion Picture]. Spain, Italy, Turkey.

Öztek, A. (2007, September 7). Türkiye sinemasında eşcinsellik. Retrieved January 17, 2017, from KAOS GL.

http://web.archive.org/web/20110120144009/http://www.kaosgl.com:80/content/turki ye-sinemasinda-escinsellik

Pew Research Center. (20007). Pew global attitudes project: Spring 2007 survey. Pew Research Center.

Queer Düş'ün Serisi. (2016). Retrieved January 18, 2017, from Sel Yayıncılık. http://www.selyayincilik.com/kitaplar/queer-dusun-serisi/

Renay, M. (2012). Ben senin bildiğin erkeklerden değilim. GOA Basın Yayın.

Renay, M. (2013, August 1). İşte "öteki" erkekler. Git\&Yap, p. 118.

Sancaktaroğlu Bozkurt, S. (2019). Queer edebiyatı. Lacivert, 15(89), 42-70.

Savcl, E. (2021). Queer in translation: Sexual politics under neoliberal Islam. Duke University Press.

Savci, E. (2011). Queer in translation: Paradoxes of westernization and sexual others in the Turkish nation. [Unpublished doctoral dissertation], University of Southern California, Los Angeles.

Sayılıgil, F. (Ed.). (2016). Toplumsal cinsiyet tartışmaları. Dipnot Yayınevi.

Seden, O. F., Gülgen, M. (Writers), Seden, O. F., \& Gülgen, M. (Directors). (1980). Beddua [Motion Picture]. Turkey. 
Sel Yayıncılık. (2016). Hakkımızda. Retrieved January 18, 2017, from http://www.selyayincilik.com/hakkimizda

Sel Yayıncılık. (2016). Toplumsal cinsiyet yanılsaması. Retrieved January 19, 2017, from http://www.selyayincilik.com/kitap/toplumsal-cinsiyet-yanilsamasi-707

Sela-Sheffy, R. (2003). Interference and aspects of repertoire consolidation in culture. In M. Bietak, \& O. Goldwasser (Eds.), The challenge of the Hyksos: Cultural interference in the New Kingdom (pp. 1-12). Austrian Academy of Sciences.

Sela-Sheffy, R., \& Shlesinger, M. (2008). Strategies of image-making and status advancement of translators and interpreters as a marginal occupational group. In A. Pym, M. Shlesinger, \& D. Simeoni (Eds.), Beyond descriptive translation studies: Investigations in homage to Gideon Toury. (pp. 79-90). John Benjamins.

Serin, B., \& Özlen, H. (2017, April 1). Söyleşi: Irfan Sancı. Retrieved June 7, 2021, from Pan dergi. https://www.pandergi.com/single-post/2017/04/01/s\%C3\%B6yle\%C5\%9Fi¡\%CC\%87rfan-sanc\%C4\%B1

Solmaz, F. (2018). Gore Vidal'in "Kent ve Tuz" eserinin kuir kültürü ve camp talk çevirisi üzerinden çeviri eleştirisi. Fe Dergi , 10(1), 12-26.

Soydan, S. (2020). Ah Bu Sevda! - Türk edebiyatında "öteki" cinsellik öyküleri 1872-1928. Sel Yayıncilık.

Stevens, H. (2011). Gey ve lezbiyen yazını. (K. Tanrıyar, Trans.) Sel Yayıncılık. (Original work published 2010)

Su, D. (2011, December 1). Özgür yayıncllık! Time out İstanbul, p. 206.

Susel, K. (2019). Translating Bülent Ersoy's stylized gender performances in the end of fame: A case study [Unpublished doctoral dissertation], State University of New York.

Şeker, B. (Ed.). (2013). Başkaldıran bedenler: Türkiye'de transgender, aktivizm ve altkültürel pratikler. Metis Yayıncılık.

Şevki, A. (2009). Edebiyat ve yorum. Havuz Yayınları.

Şimşek Aksin, M. (2019). Queer ve feminist pedagojiler temelinde Ankara'da lise öğretmenleri üzerine bir araştırma [Unpublished master's thesis], Hacettepe University.

Tabur, i. (2014, September 15). Saflar belli olsun. Retrieved May 30, 2021, from 5Harfliler. https://www.5harfliler.com/saflar-belli-olsun/

Tahir Gürçağlar, Ş. (2008). The politics and poetics of translation in Turkey, 1923 - 1960. Rodopi.

Tahir, K., Refiğ, H. (Writers), \& Refiğ, H. (Director). (1965). Haremde dört kadın [Motion Picture]. Turkey: Birsel Film.

Tahir, K., Yılmaz, A. (Writers), \& Yılmaz, A. (Director). (1963). iki gemi yanyana [Motion Picture]. Turkey: Efe Film. 
Tanır, K. Ş. (2019). Ifade özgürlüğü ve nefret söylemi dilemması: Türk medyasında queer teoriyi ifade özgürlüğü ve nefret söylemi ikilemiyle okumak [Unpublished master's thesis], İstanbul University.

Tanrıyar, K. (2010). Öykünmekle ilgili. Retrieved January 19, 2017, from http://oykunmekleilgili.blogspot.com.tr

Tanrıyar, K. (2011, April 6). Toplumsal cinsiyet yanılsaması. Retrieved January 19, 2017, from Kaos GL. https://kaosgl.org/haber/toplumsal-cinsiyet-yanilsamasi

Tar, Y. (2018, August 13). Labirente davet: Homofobi sözlüğü. Retrieved February 4, 2021, from Kaos GL. https://kaosgl.org/gokkusagi-forumu-kose-yazisi/labirente-davet-homofobisozlugu

Temel, A. (2016, April 8). Korkup kaçmak ve korkuyla yönelmek. Bir Gün kitap, p. 17.

Tempo Kitap. (2015, February 2). Fetiş ikame. Tempo Kitap. https://www.selyayincilik.com/basin/Flkame.jpg

Tempo Kitap. (2015, February 2). Mürekkebi kurumadan. Tempo. https://www.tempomag.com.tr/detail/murekkebi-kurumadan

Tezkan, M., \& Urun, O. (2021). About + contact. Retrieved February 4, 2021, from Biriken. http://www.biriken.com/about-contact.php

Tiftik, S. (2017). Karşılaştırmalı queer okumalar: Kulin, Mungan ve Toptaş metinlerinde queer potansiyeller [Unpublished master's thesis], İhsan Doğramacı Bilkent University.

Tin, L.-G. (2018). Homofobi sözlügüu. (M. Tezkan, \& O. Urun, Trans.) Sel Yayıncılık. (Original work published 2003)

Tiyatrolar.com.tr. (2015). Melis Tezkan. Retrieved February 4, 2021, from Tiyatrolar. https://tiyatrolar.com.tr/melis-tezkan

Tiyatrolar.com.tr. (2015). Okan Urun. Retrieved May 30, 2021, from Tiyatrolar. https://tiyatrolar.com.tr/okan-urun

Topal, i. (2019). Tekliğin ötesinde, ikiliğin arasında: Melez bir tahayyül olarak Venüs [Unpublished master's thesis], Boğaziçi University.

Torunoğlu, S. (2002). Travesti Pinokyo. Stüdyo İmge.

Tulgar, A. (2006). Volkan'ın romanı. Everest Yayınları.

Tunçsan, B. (2019). Duyguların örgütlenmesi ve yas: Queer bir yas mekânı olarak Boysan'ın evi [Unpublished master's thesis], Mimar Sinan Fine Arts University.

Türkölmez, E. (2018, June 28). Hâlâ burdayız aşkım! Retrieved February 4, 2021, from Hürriyet. https://www.hurriyet.com.tr/kitap-sanat/hala-burdayiz-askim-40880162

UI, B. (2016). Self-sensorship in the Turkish translation of Alice Walker's "The color purple". In B. Akçeşme, H. Baktir, \& E. Steele (Eds.), Interdisciplinarity, multidisciplinarity, and transdisciplinarity in humanities (pp. 192-199). Cambridge Scholars Publishing.

Uzun, M. (2013, December 14). Kuir Düş'ün. BirGün Kitap, p. 13. 
Uzunoğlu, D. (2015, December 24). "Sel, otoriteyle derdi olan bir yayınevi". Retrieved June 3, 2021, from t24. https://t24.com.tr/k24/yazi/sel-yayincilik,514

Venuti, L. (1996). Translation as a social practice: Or, the violence of translation. Translation Perspectives , IX, 195-213.

Wittig, M. (2013). Straight düşünce. (L. Darıcıoğlu, \& P. Büyüktaş, Trans.). Sel Yayıncllık. (Original work published 1992)

Wolf, M. (2007). Introduction: The emergence of a sociology of translation. In M. Wolf, \& A. Fukari (Eds.), Constructing a sociology of translation (pp. 1-36). John Benjamins.

Wolf, S. (2012). Cinsellik ve sosyalizm. (K. Tanrıyar, Trans.) Sel Yayıncılık. (Original work published 2009)

Yüce, C. (2019). Türkçe polisiye edebiyatta queer bir sapma: Mehmet Murat Somer'in Hop-ÇikiYaya Serisi [Unpublished master's thesis], Boğaziçi University.

Yıldırım, N. (2018, September 25). Homofobi sözlüğü üzerine. Retrieved February 4, 2021, from Mevzu edebiyat. http://www.mevzuedebiyat.com/homofobi-sozlugu-uzerine/

Yılmaz, E. (2019). Queer mekân olarak Maçka Demokrasi Parkı. [Unpublished master's thesis], İstanbul Bilgi University.

Yapı Kredi Yayınları. (2021). Özlem Güçlü. Retrieved February 4, 2021, from Yapı Kredi Yayınları. https://kitap.ykykultur.com.tr/cevirenler/ozlem-guclu

Yardımcı, S., \& Güçlü, Ö. (Eds.). (2013). Queer tahayyül. Sel Yayıncılık.

Yerlikaya, Ç. (2011). Fişini sen mi çektin rüyalarımın. Liman Yayınları.

Yerlikaya, Ç. (2007). Sevişen çocuklar matinesi. Liman Yayıncılık.

Zorlu, N. (2003). Hergele aşıklar. Metis Yayınları. 